\title{
Radiolabelled polymeric IgA: from biodistribution to a new molecular imaging tool in colorectal cancer lung metastases
}

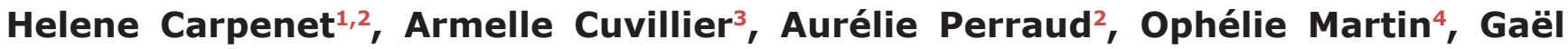 \\ Champier $^{3}$, Marie-Odile Jauberteau ${ }^{2}$, Jacques Monteil ${ }^{1,2,4}$ and Isabelle Quelven ${ }^{1,2,4}$ \\ ${ }^{1}$ Nuclear Medicine Department, Dupuytren University Hospital, 87042 Limoges, France \\ ${ }^{2}$ EA 3842 - Cellular Homeostasis and Diseases, Faculty of Medicine, University of Limoges, 87025 Limoges, France \\ ${ }^{3} \mathrm{~B}$ Cell Design SAS, 87000 Limoges, France \\ ${ }^{4}$ UMR CNRS 7276 - CRIBL, University of Limoges, 87025 Limoges, France \\ Correspondence to: Isabelle Quelven, email: isabelle.quelven@unilim.fr \\ Armelle Cuvillier, email: armelle.cuvillier@b-cell-design.com \\ Keywords: anti-CEA IgA, radiolabelling, mucosal biodistribution, metastases, colorectal cancer imaging \\ Received: December 21,2016 Accepted: July 03, $2017 \quad$ Published: July 27, 2017 \\ Copyright: Carpenet et al. This is an open-access article distributed under the terms of the Creative Commons Attribution License \\ 3.0 (CC BY 3.0), which permits unrestricted use, distribution, and reproduction in any medium, provided the original author and \\ source are credited.
}

\section{ABSTRACT}

By radiolabelling monomeric $(\mathrm{m})$ and polymeric $(\mathrm{p})$ IgA with technetium $99 \mathrm{~m}$ ( $\left.{ }^{99 m} \mathrm{TC}\right)$, this study assessed IgA biodistribution and tumour-targeting potency. IgA directed against carcinoembryonic antigen (CEA), a colorectal cancer marker, was selected to involve IgA mucosal tropism.

Ig was radiolabelled with ${ }^{99 \mathrm{~m} T c-t r i c a r b o n y l ~ a f t e r ~ d e r i v a t i s a t i o n ~ b y ~} 2$-iminothiolane. ${ }^{99 m}$ Tc-IgA was evaluated by in vitro analysis. The biodistributions of radiolabelled anti-CEA mIgA, pIgA and IgG were compared in normal mice. Anti-CEA pIgA tumour uptake was studied in mice bearing the WiDr caecal orthotopic graft.

IgA radiolabelling was obtained with a high yield, was stable in PBS and murine plasma, and did not alter IgA binding functionality (Kd $\approx 25 \mathrm{nM}$ ). Biodistribution studies in normal mice confirmed that radiolabelled pIgA - and to a lesser extent, mIgA - showed strong and fast mucosal tropism and a shorter serum half-life than IgG. In caecal tumour model mice, evaluation of the anti-CEA-pIgA biodistribution showed a high uptake in lung metastases, confirmed by histological analysis. However, no radioactivity uptake increase in the tumoural caecum was discerned from normal intestinal tissue, probably due to high IgA caecal natural tropism. In microSPECT/ CT imaging, ${ }^{99 \mathrm{~m} T c-I g A}$ confirmed its diagnostic potency of tumour in mucosal tissue, even if detection threshold by in vivo imaging was higher than post mortem studies. Contribution of the FcaRI receptor, studied with transgenic mouse model (Tsg SCIDCD89), did not appear to be determinant in $99 \mathrm{~m}$ Tc-IgA uptake.

Pre-clinical experiments highlighted significant differences between ${ }^{99 m} \mathrm{Tc}-\mathrm{IgA}$ and ${ }^{99 \mathrm{~m}} \mathrm{Tc}$-IgG biodistributions. Furthermore, tumoural model studies suggested potential targeting potency of pIgA in mucosal tissues.

\section{INTRODUCTION}

Colorectal cancer (CRC) is the most commonly diagnosed cancer worldwide. For the past few years, almost 1.4 million new cases have been diagnosed every year (representing $9.7 \%$ of all cancers), with 450,000 new cases being reported in Europe (where CRC is the second- most common cancer, representing $13 \%$ of all cancers). $\mathrm{CRC}$ is also the second-most common cause of cancerrelated deaths in Europe, with an estimated 215,000 deaths every year. Cancer survival rates are based on initial staging of the cancer at diagnosis. Optical colonoscopy remains the gold-standard investigation for early detection of CRC. Accurate staging remains critical for 
determining the most relevant treatment, and also offers prognostic and outcome indicators. However, despite the above, according to a review by Bradley no definitive consensus on the optimal imaging staging strategy has yet been established for CRC [1]. More specific and sensitive non-invasive methods are needed. One such method is immunoscintigraphy, a useful technique that has continued to expand since the 1980 s commensurate with monoclonal expansion. Monoclonal antibody $(\mathrm{mAb})$ generation in 1975 by Köhler and Milstein combined to nuclear imaging technology progress led to development of monoclonal antibodies labelled with radioactive isotopes to target tumours [2]. Concerning staging of CRC, the main interest in immunoscintigraphy lies in its sensitivity for detecting distant metastasis.

Many antibodies or antibody fragments have been developed for detecting primary tumours and distant metastasis. In cases of cancer with mucosal localisation, satumomab (Oncoscint $\left.{ }^{\circledR}\right)$ directed against glycoprotein TAG-72 radiolabelled with 111-Indium has been used in the US since 1992 for CRC diagnosis [3]. Arcitumomab $\left(\mathrm{CEA}-\mathrm{Scan}^{\circledR}\right), \mathrm{a} \mathrm{F}\left(\mathrm{ab}^{\prime}\right)_{2}$ directed against carcinoembryonic antigen (CEA) labelled with 99m-Technetium ( ${ }^{99 \mathrm{~m}} \mathrm{Tc}$ ), received FDA and EMEA approval in 1996 for diagnosis of $\mathrm{CRC}$ recurrence $[4,5]$. Another ${ }^{99 \mathrm{~m}} \mathrm{Tc}$-radiolabelled Fab, nofetumomab (Verluma ${ }^{\circledR}$ ) - directed against pancarcinoma glycoprotein antigen epithelial cell adhesion molecule (EpCAM) - was FDA-approved for the diagnosis of small cell lung cancer. Today, satumomab is the only mAb still used in the US for the immunoscintigraphy of mucosal tumour localisation. Their diagnostic value remains controversial due to the low contrast between normal and tumoural tissue, especially compared with 18-fluorodeoxyglucose positron emission tomography (FDG-PET) [6]. However, FDG is not a specific tracer as high FDG uptake in inflammatory or infectious lesions, and variable physiological concentrations in normal tissues/organs, can be confused with malignant tissue [7]. An approach to overcome the limitations of FDG-PET involves targeting molecules to localise specific tumour markers, with preferential tropism for the tissues of interest, such as mucous membranes.

Antibodies directed against CEA appear to be good candidates to target CRC. Indeed, CEA, a 180$\mathrm{kDa}$ glycoprotein, is part of a large family of 12 related members, whose functions can vary widely and include cell adhesion, participation in intracellular signal cascades, cell migration, inflammation, and angiogenesis. CEA is synthesised mainly by the digestive tract and is polarised at the apical pole in the epithelial wall. This oncofetal antigen is quite absent from healthy adult tissues. CEA is frequently expressed, with a high serum concentration, in adenocarcinomas of various origins, such as breast, medullary thyroid, lung, and ovarian cancers, as well as CRC. CEA was identified in CRC for the first time in 1965 [8]. Its expression is upregulated in approximately $90 \%$ of advanced CRC cases [9]. One in two patients diagnosed with $\mathrm{CRC}$ already has metastasis, thereby negating the use of a first-line surgical strategy; furthermore, many cases do not respond to chemotherapy. In such advanced cases, the prognosis is very poor, and the average survival time is 5 to 9 months. Although not a specific marker of CRC, CEA has prognostic value in patients with metastatic cancer. It is elevated in $58 \%$ to $65 \%$ of cases, and the first sign of recurrence can precede clinical or radiological recidivism by 1.5 to 6 months. Several clinical studies are underway to assess the relevance of targeting CEA by immunoscintigraphy for the detection of primary tumour and metastasis $[10,11]$. Nevertheless, published data are only based on the Immunoglobulin (Ig) G or IgG fragment, and no study has used $\operatorname{IgA}$. In humans, $\operatorname{IgA}$ is the most heavily produced isotype (66 mg/kg/day) and the second-most prevalent circulating isotype, after IgG. Long regarded as an anti-inflammatory antibody involved in maintaining homeostatic balance at the level of the mucous membrane, it has been demonstrated recently that IgA can enable or inhibit different inflammatory responses [12]. IgA efficacy to recruit effector cells, such as monocytes, macrophages, granulocytes and Kupffer cells, was demonstrated for antibody dependent cellmediated cytotoxicity (ADCC) [13]. IgA interaction with myeloid cells is mediated with the IgA Fc receptor, FCaRI (CD89). Importantly, mice lacking to express any human FCaRI homologue, a transgenic mouse model (Tsg SCIDCD89) was described to express human FCaRI on mouse myeloid lineage [14] and mimics effector cells recruitment and cell cytotoxicity mechanisms observed in human $[15$, $16]$ in presence of human or humanised $\operatorname{IgA}$.

IgA is expressed in three different forms: monomeric (mIgA) (in the blood: 1 to $3 \mathrm{~g} / \mathrm{L}$ ), dimeric (dIgA)/ polymeric (pIgA) (in mucous membranes) and secretory (SIgA) (in the mucosal organs). The B lymphocytes are present in the serous compartment of mucosal organs and predominantly produce dIgA (two molecules of IgA complexed by the J chain peptide). The dimers, specifically recognised by the polymeric Ig receptor ( $\mathrm{pIgR}$ ) expressed on the basal side of epithelial cells, are endocytosed and translocated to the apical side of the cells. At the time of exocytosis, the extracellular part of the pIgR is cleaved and remains complexed to the dimer, thereby forming the secretory component, the SIgA [12]. Moreover, dIgA has a cell signalling capacity greater than that of monomeric IgA because the dimer carries twice as many paratopes [16]. Knowledge of $\operatorname{IgA}$ and its applications is limited partly due to difficulties in the identification of $\operatorname{IgA}$ producing $\mathrm{B}$ cells, and with respect to stable production of IgA antibodies. IgA-secreting B lymphocytes represent less than $1 \%$ of normal mouse splenocytes (even fewer are found in mucosal lymphoid compartments: $0.01 \%$ in the lamina propria and $0.1 \%$ in Peyer's patches) [17]. The recently developed HAMIGA ${ }^{\text {TM }}$ technology allows this limitation to be bypassed [18]. By replacing the $\mathrm{S} \mu$ domain with a human alpha 1 constant gene downstream of variable gene segments, the population of IgA-secreting 
lymphocytes B in the spleen was increased significantly $\left(62 \%\right.$ of $\mathrm{B} 220^{+}$membrane $\mathrm{IgA}$ cells in the spleen of HAMIGA $^{\text {TM }}$ mice versus undetectable level in wild-type mice) [18] which allows to easily sort highly specific monoclonal humanised IgA. From immunised transgenic human $\alpha 1$ mice, IgA1 were produced in hybridoma, B lymphocyte hybrid cells, using its dedicated glycosylation pathways of antibodies.

Concerning $\operatorname{IgA}$ application in nuclear medicine, ${ }^{99 \mathrm{~m}} \mathrm{Tc}$ remains the most widely used isotope for diagnosis, due to its suitable nuclear and chemical properties, and good availability [19]. This radionuclide has favourable physical characteristics for high-efficiency detection in molecular imaging (with a $\gamma$-ray of $140 \mathrm{keV}$ ) and for radiation protection due to a short half-life $\left(\mathrm{T}_{1 / 2}=6 \mathrm{~h}\right)$. This short half-life is not optimal for IgG (serum half-life 20 days) radiolabelling but seems suitable considering the shorter half-life of IgA (3-6 days). In a previous study, we showed that indirect radiolabelling using a bifunctional chelating agent, such as the tricarbonyl core $\left[\mathrm{Tc}(\mathrm{CO})_{3}\left(\mathrm{H}_{2} \mathrm{O}\right)_{3}\right]^{+}$, and a spacer such as 2-iminothiolane (2IT), provides good radiolabelling yields with high specific activity, and preserves IgG structure and immunoaffinity with limited amounts of antibody [20].

Here, by radiolabelling with ${ }^{99 \mathrm{~m}} \mathrm{Tc}$, we report the natural pharmacokinetic and biodistribution of different isotypes of antibodies, IgA directed against CEA, compared with IgG in healthy mice and in a xenograft mouse model of human colon carcinoma. This model enables us to evaluate the mucosal tropism of $\operatorname{IgA}$ antibodies and to test the ability of IgA antibodies, directed against a well-characterised human tumour-associated antigen, to detect early-stage mucosal metastasis foci.
Biodistribution was firstly evaluated by post mortem organs counting. This most sensitive technique is the gold standard to evaluate accurately molecule biodistribution, but needs animals sacrifice. MicroSPECT/CT studies, which are less sensitive but allow in vivo monitoring, were compared to gold standard method. Using the transgenic mouse model expressing the high affinity receptor FC $\alpha$ RI (Tsg SCID-CD89), we also evaluate the contribution of $\mathrm{FC} \alpha \mathrm{RI}$ in the distribution and the capacity of IgA to detect tumour in vivo by microSPECT/CT imaging.

\section{RESULTS}

\section{IgA radiolabelling and ${ }^{99 m}$ Tc-IgA-SH in vitro stability}

To optimise IgA radiolabelling with the tricarbonyl core, increasing quantities of antibody were tested by derivatisation with 2-IT (Figure 1). Native and functionalised IgA (IgA-SH) radiolabelling yields were correlated with the IgA amounts. The maximum quantity usable prior to IgA precipitation (maximum concentration $=2 \mathrm{mg} / \mathrm{mL}$ ) is $2.2 \mathrm{nmol}$ of $\operatorname{IgA}$. With this amount of native $\operatorname{IgA}$, only $45 \%$ radiochemical purity (RCP) was reached. With derivatised IgA, much higher yields were achieved ( $\mathrm{RCP}=98 \%)$ for this maximum IgA quantity, and an RCP $>85 \%$ was obtained from only $1 \mathrm{nmol}$ of IgA. These results confirmed that the derivatisation of $\operatorname{IgA}$ is necessary to obtain high radiolabelling of RCP. After determining the sulphydryl groups by using the micromethod and Ellman's reagent, a correlation between the radiolabelling yields and number of thiol moieties on

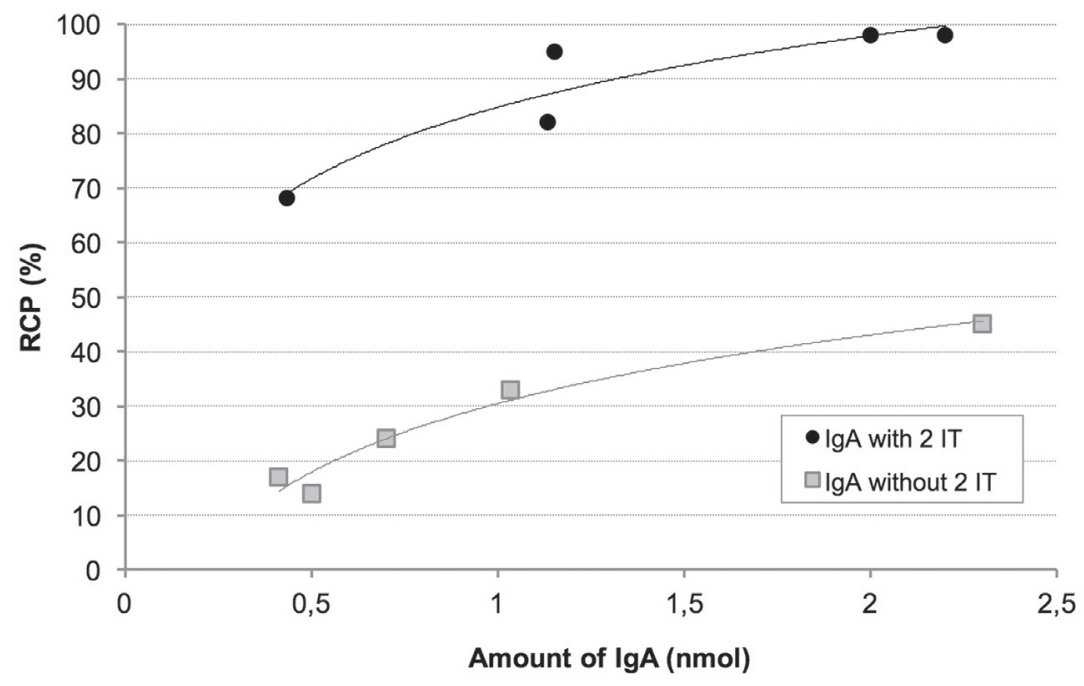

Figure 1: Comparison of native and 2-IT derivatised radiolabelled IgA yields according to IgA amount. Radiochemical purity (RCP) analysis was performed using instant thin layer chromatography-silica gel (ITLC-SG)/normal saline. 
IgA was clearly seen, confirming derivatisation (data not shown). With derivatised $\operatorname{IgA}$, on average, $1.7 \pm 0.4(n=$ 3 ) sulphydryl groups were grafted to each IgA molecule; with native $\operatorname{IgA}$, the number was below the limit of quantification. With these optimised conditions (1.4 nmol of derivatised $\operatorname{IgA})$, radiolabelling yields $>96.6 \pm 2.1 \%(n$ $=13$ ) were obtained. The specific activity corresponded to $115 \mathrm{MBq} / \mathrm{nmol}$ (511 MBq/mg).

Stability testing of ${ }^{99 \mathrm{~m}} \mathrm{Tc}-\mathrm{IgA}-\mathrm{SH}$ was performed over $24 \mathrm{~h}$ in phosphate-buffered saline (PBS), with storage at $4^{\circ} \mathrm{C}$ or $25^{\circ} \mathrm{C}$, and in murine serum $(1 / 10$ dilution) at $37^{\circ} \mathrm{C}$. In PBS, no appreciable loss in RCP was seen (at 24 h: $\triangle \mathrm{RCP}=4 \%$ and $8 \%$, at $4^{\circ} \mathrm{C}$ and $25^{\circ} \mathrm{C}$, respectively). However, after incubation in murine serum (1/10 dilution) at $37^{\circ} \mathrm{C}$, a gradual decrease in radiolabelled IgA RCP was observed (at $18 \mathrm{~h}$ and $24 \mathrm{~h}: \triangle \mathrm{RCP}=13 \%$ and $23 \%$, respectively).

\section{Integrity of ${ }^{99 \mathrm{~m}} \mathrm{Tc}-\mathrm{IgA-SH}$}

To demonstrate full preservation of molecular integrity during the radiolabelling process, unlabelled and radiolabelled IgA samples of monomeric and polymeric mixture (mpIgA) were analysed by Sodium dodecyl sulphate-polyacrylamide gel electrophoresis (SDS-PAGE) (Figure 2).

Western blot profiles of mpIgA showed major bands at $120-140 \mathrm{kDa}$ and $300-400 \mathrm{kDa}$, corresponding to the molecular weight of monomeric and polymeric forms, respectively, for both unlabelled IgA (lanes 2-3) and radiolabelled IgA (lanes 4-5). As expected, the molecular structure of IgA was preserved after radiolabelling; no low-molecular-weight band corresponding to free heavy chain release appeared for either radiolabelled antibody. A slight decrease in intensity was observed between

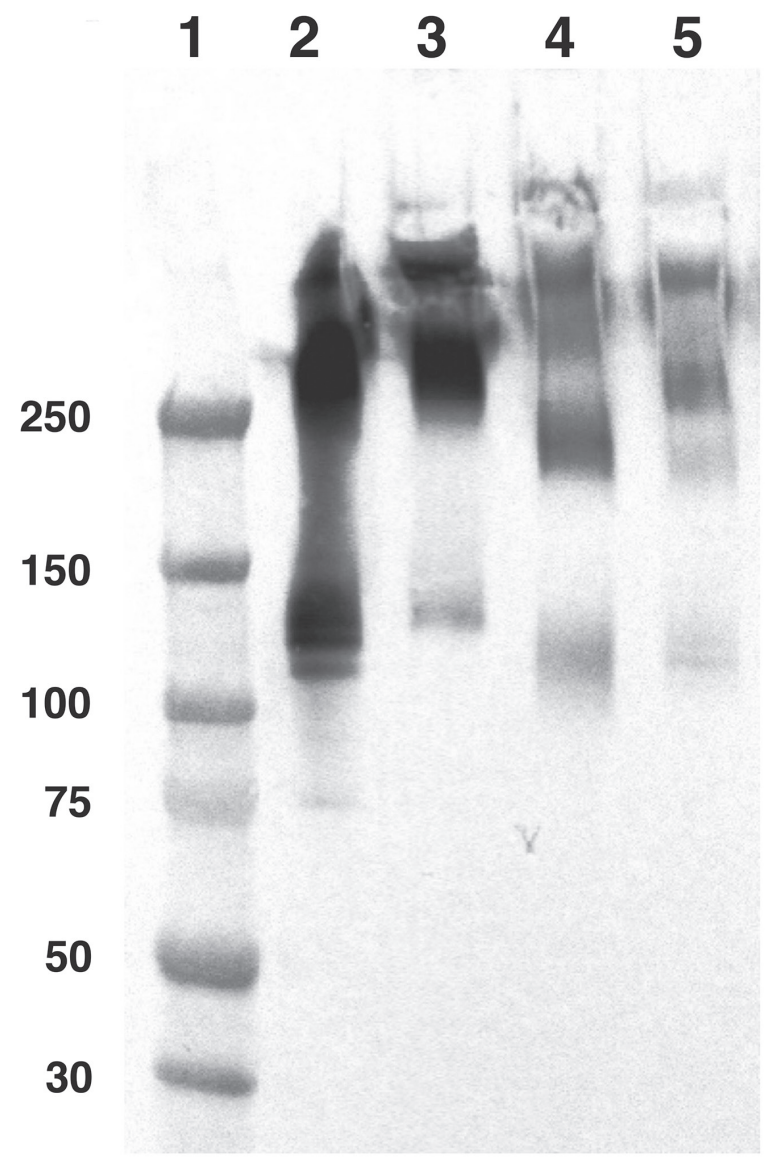

Figure 2: Molecular structure comparison of unlabelled and radiolabelled anti-carcinoembryonic antigen (CEA) or irrelevant monomeric and polymeric mixture (mpIgA). Anti-CEA or irrelevant mpIgA molecular structure was evaluated by Western blotting. Molecular weights in $\mathrm{kDa}$ are specified on the left. 1. Molecular weight Marker, 2. Unlabelled anti-CEA mpIgA-SH (monomeric $\approx 150 \mathrm{kDa}$ and polymeric $>250 \mathrm{kDa})(1.5 \mathrm{mg}), 3$. Unlabelled irrelevant mpIgA-SH (1.5 mg), 4. Radiolabelled anti-CEA mpIgA (1.5 mg), 5. Radiolabelled irrelevant mpIgA-SH (1.5 mg). 
unlabelled and radiolabelled antibodies due to Ig loss during the purification after incubation with 2-IT.

\section{Affinity of ${ }^{99 \mathrm{~m}} \mathrm{Tc}-\mathrm{IgA}-\mathrm{SH}$}

Immunoaffinity evaluation by radioimmunoassay (RIA) allowed us to observe that the radiolabelled anti-CEA IgA-SH has a high affinity for the target antigen (Figure 3A). The specific binding of ${ }^{99} \mathrm{~m}$ Tc-anti-CEA IgA-SH was confirmed by displacement with unlabelled anti-CEA IgA. The dissociation constant $(\mathrm{Kd})$ and maximum number of antibody bound of ${ }^{99 m}$ Tc-anti-CEA IgA-SH were estimated using a saturation binding assay and Scatchard analysis (Figure 3C). The assays provided a value of $20.3 \mathrm{nM}$ for the $\mathrm{Kd}$ and $3.2 \mathrm{nM}$ for the binding capacities $\left(\mathrm{B}_{\max }\right)$. Specific binding was also confirmed by lack of fixation of an irrelevant IgA ( ${ }^{99 \mathrm{~m}} \mathrm{Tc}$-anti-peanut $\left.\mathrm{IgA}-\mathrm{SH}\right)$.

The immunoaffinity of ${ }^{99 m}$ Tc-anti-CEA IgA-SH was also assessed using a saturation binding assay on the WiDr colon adenocarcinoma cell line, which expresses the fully folded membranal antigen (Figure 3B). This assay showed specific saturable binding. Using the Scatchard representation data, the calculated $\mathrm{Kd}$ and $\mathrm{B}_{\max }$ were $30.5 \mathrm{nM}$ and $1.2 \mathrm{nM}$, respectively (Figure 3D). The controls were performed with ${ }^{99 \mathrm{~m}}$ Tc-anti-CEA IgA-
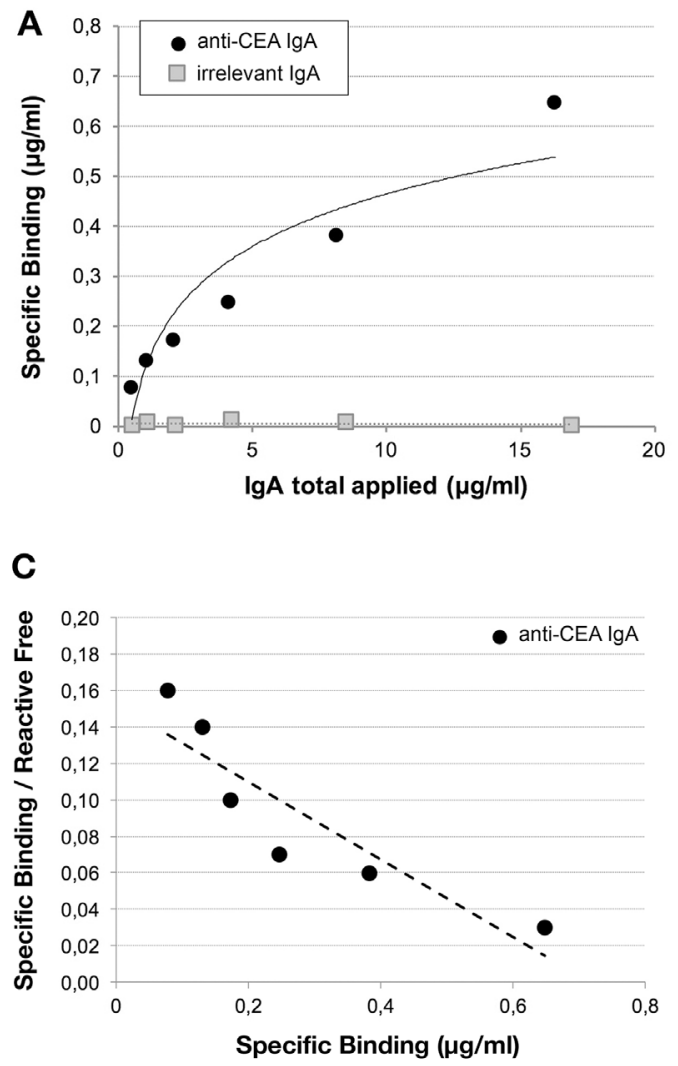

SH on non-expressing CEA cells (DLD1; another colon adenocarcinoma cell line) and with irrelevant IgA on WiDr cells. As expected, no binding was observed under either of these conditions.

\section{Biodistribution of ${ }^{99 \mathrm{~m}} \mathrm{Tc}$-anti-CEA IgA-SH and ${ }^{99 m}$ Tc-anti-CEA IgG-SH in normal mice}

Comparison of the in vivo biodistribution kinetics of ${ }^{99 \mathrm{~m} T c-a n t i-C E A}$ polymeric IgA-SH, ${ }^{99 m} \mathrm{Tc}-a n t i-C E A$ monomeric IgA-SH and ${ }^{99 m}$ Tc-anti-CEA IgG-SH in healthy $\mathrm{BALB} / \mathrm{c}$ mice are presented for all studied organs in Tables 1-3, respectively, and for selected organs in Figure 4.

Global analysis (i.e. whole-organ study) of radioactivity uptake (percentage of the injected dose per gram of tissue: $\% \mathrm{ID} / \mathrm{g})$ showed a significant $(\mathrm{p}<0.002)$ difference among the three Ig types at $8 \mathrm{~h}, 24 \mathrm{~h}$ and 48 h. However, although no significant difference was observed in global analysis at $4 \mathrm{~h}$ among the three Ig types, an important difference in the radioactivity uptake was observed between the caecum and faeces. At this early time, high uptake was measured, in the caecum and faeces, of ${ }^{99 m}$ Tc-anti-CEA pIgA-SH $(27.0 \pm$ 4.9 and $30.6 \pm 9.3 \% \mathrm{ID} / \mathrm{g}$, respectively) and, to a lesser
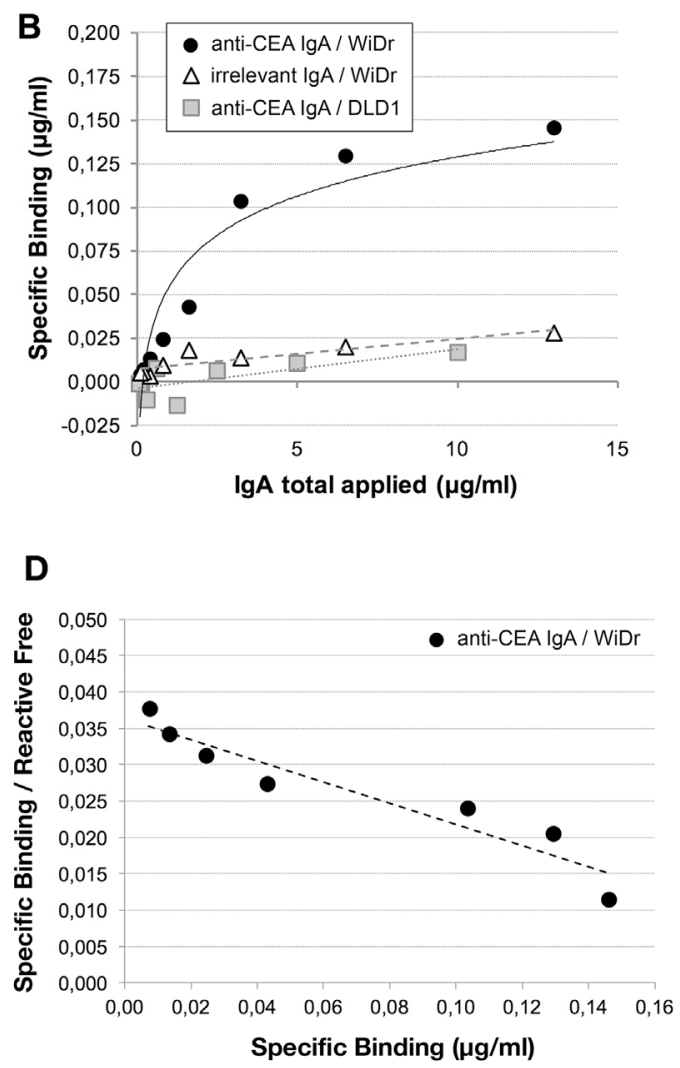

Figure 3: In vitro binding of ${ }^{99} \mathrm{~m}$ Tc-anti-CEA IgA-SH and ${ }^{99} \mathrm{~m}$ Tc-irrelevant IgA-SH. Radiolabelled IgA specific binding was evaluated by RIA protocol (A) and on cells (B). For cells studies, WiDr (CEA pos) and DLD1 (CEA neg) cell lines were tested. For the two experiments, Kd and Bmax were evaluated by a Scatchard plot (C: RIA; D: cells). 
Table 1: Biodistribution of ${ }^{99 \mathrm{~m}}$ Tc-anti-CEA IgA polymeric-SH in healthy Balb-c mice at 4, 8, 18, 24 and 48h, expressed as the percentage of injected (intravenous; IV) dose per gram, \% ID/g (values represent means \pm S.D. of the $\%$ ID/g)

\begin{tabular}{|c|c|c|c|c|c|}
\hline & $\begin{array}{c}4 h \\
(n=4)\end{array}$ & $\begin{array}{c}8 h \\
(n=4)\end{array}$ & $\begin{array}{c}18 h \\
(n=4)\end{array}$ & $\begin{array}{c}24 h \\
(n=8)\end{array}$ & $\begin{array}{c}48 h \\
(n=4)\end{array}$ \\
\hline Heart & $5.4 \pm 2.5$ & $3.0 \pm 0.3$ & $2.4 \pm 0.1$ & $1.9 \pm 0.8$ & $1.2 \pm 0.4$ \\
\hline Brain & $0.33 \pm 0.09$ & $0.22 \pm 0.04$ & $0.10 \pm 0.03$ & $0.11 \pm 0.04$ & $0.05 \pm 0.01$ \\
\hline Lungs & $7.8 \pm 2.7$ & $5.2 \pm 0.7$ & $3.4 \pm 1.1$ & $3.3 \pm 1.1$ & $2.3 \pm 1.0$ \\
\hline Kidneys & $21.4 \pm 6.9$ & $16.0 \pm 5.1$ & $11.6 \pm 6.1$ & $11.0 \pm 6.6$ & $7.9 \pm 4.6$ \\
\hline Spleen & $16.5 \pm 6.0$ & $12.2 \pm 3.5$ & $6.9 \pm 2.7$ & $6.5 \pm 1.1$ & $3.9 \pm 1.7$ \\
\hline Stomach & $2.7 \pm 1.5$ & $1.1 \pm 0.4$ & $1.5 \pm 1.3$ & $0.7 \pm 0.3$ & $0.5 \pm 0.2$ \\
\hline Small intestine & $5.2 \pm 1.0$ & $3.2 \pm 0.6$ & $1.5 \pm 0.7$ & $1.1 \pm 0.4$ & $0.6 \pm 0.2$ \\
\hline Caecum & $27.0 \pm 4.9$ & $11.2 \pm 4.5$ & $2.8 \pm 1.7$ & $3.2 \pm 2.1$ & $1.4 \pm 0.7$ \\
\hline Colon & $6.7 \pm 2.0$ & $3.4 \pm 1.3$ & $1.5 \pm 0.8$ & $1.1 \pm 0.4$ & $0.7 \pm 0.4$ \\
\hline Liver & $66.4 \pm 19.4$ & $49.0 \pm 18.4$ & $19.2 \pm 3.9$ & $24.4 \pm 11.0$ & $16.9 \pm 7.6$ \\
\hline Muscle & $1.6 \pm 0.5$ & $1.4 \pm 0.6$ & $0.9 \pm 0.5$ & $0.6 \pm 0.2$ & $0.5 \pm 0.3$ \\
\hline Blood cells & $3.3 \pm 0.8$ & $2.0 \pm 0.5$ & $4.6 \pm 2.0$ & $2.1 \pm 1.2$ & $1.3 \pm 0.5$ \\
\hline Plasma & $19.2 \pm 4.3$ & $10.0 \pm 1.3$ & $1.3 \pm 0.5$ & $2.8 \pm 1.9$ & $0.9 \pm 0.4$ \\
\hline Faeces & $30.6 \pm 9.3$ & $6.9 \pm 4.4$ & $3.9 \pm 2.6$ & $2.1 \pm 1.2$ & $0.9 \pm 0.6$ \\
\hline Mesenteric Ganglion & $4.9 \pm 3.1$ & $3.0 \pm 1.6$ & $1.05 \pm 0.3$ & $1.8 \pm 1.7$ & $0.5 \pm 0.2$ \\
\hline
\end{tabular}

Table 2: Biodistribution of ${ }^{99 m}$ Tc-anti-CEA IgA monomeric-SH in healthy Balb-c mice at 4, 8, 18, 24 and 48h, expressed as the percentage of injected (IV) dose per gram, \%ID/g (values represent means \pm S.D. of the \%ID/g)

\begin{tabular}{|c|c|c|c|c|c|}
\hline & $\begin{array}{c}4 h \\
(n=4)\end{array}$ & $\begin{array}{c}8 h \\
(n=4)\end{array}$ & $\begin{array}{c}18 h \\
(n=3)\end{array}$ & $\begin{array}{c}24 h \\
(n=7)\end{array}$ & $\begin{array}{c}48 h \\
(n=4)\end{array}$ \\
\hline Heart & $6.0 \pm 0.8$ & $3.4 \pm 0.3$ & $3.4 \pm 1.4$ & $1.7 \pm 0.8$ & $1.6 \pm 0.3$ \\
\hline Brain & $0.44 \pm 0.06$ & $0.28 \pm 0.04$ & $0.17 \pm 0.11$ & $0.12 \pm 0.04$ & $0.07 \pm 0.02$ \\
\hline Lungs & $7.8 \pm 1.6$ & $5.3 \pm 0.7$ & $5.8 \pm 3.0$ & $3.4 \pm 1.2$ & $3.0 \pm 1.3$ \\
\hline Kidneys & $20.0 \pm 4.0$ & $15.8 \pm 6.0$ & $16.2 \pm 9.2$ & $12.1 \pm 6.9$ & $9.8 \pm 3.5$ \\
\hline Spleen & $27.2 \pm 4.0$ & $18.6 \pm 6.5$ & $52.6 \pm 14.1$ & $34.8 \pm 19.5$ & $41.4 \pm 8.7$ \\
\hline Stomach & $2.7 \pm 1.7$ & $0.9 \pm 0.4$ & $0.9 \pm 0.7$ & $1.0 \pm 0.7$ & $0.8 \pm 0.5$ \\
\hline Small intestine & $1.9 \pm 1.8$ & $3.1 \pm 0.5$ & $2.2 \pm 1.2$ & $1.9 \pm 0.6$ & $1.5 \pm 0.4$ \\
\hline Caecum & $16.7 \pm 4.0$ & $9.8 \pm 4.8$ & $3.9 \pm 2.2$ & $3.0 \pm 1.3$ & $2.1 \pm 1.3$ \\
\hline Colon & $4.7 \pm 1.2$ & $3.0 \pm 1.3$ & $1.8 \pm 1.0$ & $1.9 \pm 1.1$ & $2.8 \pm 2.7$ \\
\hline Liver & $50.6 \pm 12.4$ & $34.7 \pm 11.5$ & $32.3 \pm 8.7$ & $24.1 \pm 8.1$ & $21.3 \pm 4.4$ \\
\hline Muscle & $1.7 \pm 0.6$ & $1.5 \pm 0.8$ & $1.7 \pm 1.2$ & $0.8 \pm 0.6$ & $0.5 \pm 0.1$ \\
\hline Blood cells & $4.6 \pm 2.4$ & $3.1 \pm 1.7$ & $1.5 \pm 0.8$ & $1.3 \pm 0.7$ & $2.2 \pm 0.6$ \\
\hline Plasma & $29.6 \pm 5.7$ & $14.3 \pm 1.5$ & $6.5 \pm 1.8$ & $4.7 \pm 1.6$ & $2.0 \pm 0.9$ \\
\hline Faeces & $14.3 \pm 4.6$ & $14.1 \pm 13.9$ & $4.7 \pm 2.9$ & $2.4 \pm 1.5$ & $2.6 \pm 1.9$ \\
\hline Mesenteric Ganglion & $4.5 \pm 2.9$ & $3.0 \pm 0.7$ & $2.0 \pm 0.8$ & $1.4 \pm 0.3$ & $0.8 \pm 0.2$ \\
\hline
\end{tabular}


Table 3: Biodistribution of ${ }^{99 \mathrm{~m}} \mathrm{Tc}$-anti-CEA IgG-SH in healthy Balb-c mice at 4, 8, 18, 24 and 48h, expressed as the percentage of injected (IV) dose per gram, \%ID/g (values represent means \pm S.D. of the $\% \mathrm{ID} / \mathrm{g}$ )

\begin{tabular}{lccccc}
\hline & $\begin{array}{c}\mathbf{4 h} \\
(\mathbf{n}=\mathbf{4})\end{array}$ & $\begin{array}{c}\mathbf{8 h} \\
(\mathbf{n}=\mathbf{4})\end{array}$ & $\begin{array}{c}\mathbf{1 8 h} \\
(\mathbf{n}=\mathbf{4})\end{array}$ & $\begin{array}{c}\mathbf{2 4 h} \\
(\mathbf{n}=\mathbf{4})\end{array}$ & $\begin{array}{c}\mathbf{4 8 h} \\
(\mathbf{n}=\mathbf{4})\end{array}$ \\
\hline Heart & $9.8 \pm 4.8$ & $8.9 \pm 1.7$ & $4.0 \pm 2.1$ & $3.6 \pm 1.6$ & $2.7 \pm 1.3$ \\
Brain & $0.61 \pm 0.39$ & $0.58 \pm 0.07$ & $0.28 \pm 0.22$ & $0.23 \pm 0.08$ & $0.21 \pm 0.10$ \\
Lungs & $16.5 \pm 9.3$ & $16.0 \pm 6.0$ & $7.9 \pm 3.4$ & $6.9 \pm 2.0$ & $5.0 \pm 1.3$ \\
Kidneys & $28.2 \pm 13.9$ & $29.5 \pm 3.3$ & $16.3 \pm 7.2$ & $15.6 \pm 6.6$ & $10.9 \pm 5.0$ \\
Spleen & $37.6 \pm 16.2$ & $28.3 \pm 8.5$ & $18.9 \pm 13.2$ & $17.9 \pm 8.7$ & $12.6 \pm 4.2$ \\
Stomach & $3.3 \pm 2.7$ & $3.9 \pm 0.3$ & $1.3 \pm 0.4$ & $1.6 \pm 0.7$ & $1.1 \pm 0.3$ \\
Small intestine & $5.3 \pm 2.3$ & $4.9 \pm 0.7$ & $3.5 \pm 1.6$ & $3.2 \pm 0.6$ & $1.6 \pm 0.4$ \\
Caecum & $6.1 \pm 3.6$ & $7.9 \pm 1.9$ & $3.7 \pm 2.1$ & $4.4 \pm 1.4$ & $2.0 \pm 0.3$ \\
Colon & $3.8 \pm 2.0$ & $4.5 \pm 0.2$ & $2.2 \pm 1.0$ & $3.2 \pm 1.2$ & $1.5 \pm 0.5$ \\
Liver & $29.8 \pm 16.3$ & $45.5 \pm 16.1$ & $18.6 \pm 7.3$ & $21.4 \pm 4.5$ & $15.7 \pm 2.0$ \\
Muscle & $1.6 \pm 1.0$ & $3.3 \pm 0.9$ & $1.2 \pm 0.7$ & $1.2 \pm 0.7$ & $0.9 \pm 0.5$ \\
Blood cells & $6.6 \pm 2.7$ & $6.8 \pm 4.5$ & $1.9 \pm 0.9$ & $1.6 \pm 0.5$ & $1.6 \pm 0.7$ \\
Plasma & $45.3 \pm 21.0$ & $29.3 \pm 8.0$ & $13.7 \pm 7.9$ & $12.1 \pm 4.1$ & $8.0 \pm 1.8$ \\
Faeces & $5.2 \pm 3.7$ & $6.5 \pm 2.5$ & $2.9 \pm 0.9$ & $8.1 \pm 2.7$ & $1.8 \pm 0.5$ \\
Mesenteric Ganglion & $3.6 \pm 3.6$ & $5.9 \pm 1.9$ & $2.1 \pm 1.4$ & $2.8 \pm 2.3$ & $2.0 \pm 1.5$ \\
\hline
\end{tabular}

extent, ${ }^{99 \mathrm{~m} T c-a n t i-C E A} \mathrm{mIgA}-\mathrm{SH}(16.7 \pm 4.0$ and 14.3 $\pm 4.6 \% \mathrm{ID} / \mathrm{g}$, respectively). In contrast, the uptake of ${ }^{99 m} \mathrm{Tc}-$ anti-CEA IgG-SH was lower $(6.1 \pm 3.6$ and $5.2 \pm$ $3.8 \% \mathrm{ID} / \mathrm{g}$, respectively). Eight hours' post-injection, significant differences among the three Ig types were observed in the plasma and blood-rich tissues (heart, spleen, lungs). Higher radioactivity was observed with IgG (in plasma: $29.3 \pm 8.0$ and $12.1 \pm 4.1 \% \mathrm{ID} / \mathrm{g}$ at $8 \mathrm{~h}$ and $24 \mathrm{~h}$, respectively), than with $\mathrm{mIgA}(14.3 \pm 1.5$ and $4.7 \pm 1.6 \% \mathrm{ID} / \mathrm{g}$, respectively) or $\mathrm{pIgA}(10.0 \pm 1.3$ and $2.8 \pm 1.9 \% \mathrm{ID} / \mathrm{g}$, respectively). Furthermore, beyond 18 $\mathrm{h}$, strong radioactivity uptake was observed for $\mathrm{mIgA}$ in the spleen (at $18 \mathrm{~h}: 52.6 \pm 14.1 \% \mathrm{ID} / \mathrm{g}$; at $48 \mathrm{~h}: 41.4 \pm$ $8.7 \% \mathrm{ID} / \mathrm{g}$ ), whereas no uptake was seen for $\mathrm{pIgA}$ or IgG. High radioactivity uptake was also recorded in the liver for all three Ig types. This uptake was more important for pIgA at $4 \mathrm{~h}$ (pIgA: $66,4 \pm 19,4 \% \mathrm{ID} / \mathrm{g}, \mathrm{mIgA}: 50,6 \pm 12,4$ $\% \mathrm{ID} / \mathrm{g}$, IgG: $29,8 \pm 16,3 \% \mathrm{ID} / \mathrm{g}$ ) but the difference among the three Ig types was not significant.

\section{Biodistribution of ${ }^{99 \mathrm{~m}} \mathrm{Tc}$-anti-CEA pIgA-SH and ${ }^{99 m} \mathrm{Tc}$-irrelevant $\mathrm{pIgA-SH}$ in a mouse colorectal tumour model}

According to the biodistribution results in normal mice (pIgA-SH higher uptake in the caecum), biodistribution studies of ${ }^{99 \mathrm{~m}} \mathrm{Tc}$-anti-CEA pIgA-SH at 4 $\mathrm{h}$ and $8 \mathrm{~h}$ were performed in a mouse CRC orthotopic graft model (Table 4) and compared with irrelevant IgA ( ${ }^{99 \mathrm{~m}} \mathrm{Tc}$-anti-peanut $\left.\mathrm{pIgA}-\mathrm{SH}\right)$ and healthy nude mice to evaluate the in vivo CEA affinity of IgA. All of the mice included in the studies had macroscopic colorectal tumours in the caecum observed after dissection. A notable accumulation of radioactivity was found in the "faeces-removed" tumoural caecum $(15.8 \pm 5.5$ and $18.5 \pm 8.5 \% \mathrm{ID} / \mathrm{g}$ at $4 \mathrm{~h}$ and $8 \mathrm{~h}$, respectively), but this radioactivity uptake was not significantly different from that of the two controls ${ }^{99 \mathrm{~m}} \mathrm{Tc}$-irrelevant pIgASH: $16.7 \pm 6.9$ and $11.5 \pm 6.5 \% \mathrm{ID} / \mathrm{g}$; nude mouse control: $7.9 \pm 2.5$ and $19.9 \pm 1.4 \% \mathrm{ID} / \mathrm{g}$ ). The pattern of distribution of ${ }^{99 \mathrm{~m}} \mathrm{Tc}$-anti-CEA pIgA-SH between the different organs in the mouse colorectal tumour model was similar to that observed in healthy mouse. However, a significant uptake in the lungs of ${ }^{99 \mathrm{~m}} \mathrm{Tc}$-anti-CEA pIgASH was observed after as early as $4 \mathrm{~h}$ after injection, and doubled at $8 \mathrm{~h}$ (at $4 \mathrm{~h}: 42.8 \pm 59.4 \% \mathrm{ID} / \mathrm{g}$; at $8 \mathrm{~h}$ : $97.6 \pm 29.5 \% \mathrm{ID} / \mathrm{g}$ ). This uptake was significantly more intense $(p<0.001)$ than the low fixation observed in the lungs at $4 \mathrm{~h}$ or $8 \mathrm{~h}$ after the injection of irrelevant ${ }^{99 \mathrm{~m}} \mathrm{Tc}-\mathrm{pIgA}-\mathrm{SH}$, as well as in the nude mouse control. For some animals ( $\mathrm{n}=1-3$, depending on group), a tumour was present in the peritoneal cavity opposite the injection site. On these cases, uptake was measured and found to be significantly higher with anti-CEA pIgA than with irrelevant pIgA $(2.9 \pm 1.4$ and $1.5 \pm 0.5 \% \mathrm{ID} / \mathrm{g}$, respectively; $\mathrm{p}=0.0479$ ). 


\section{Pathological analysis of the caecum and lungs}

The caecum and lungs in the mouse colorectal tumour model were sliced and analysed using coloration techniques and immunohistochemistry (Figure 5). HES analysis confirmed the presence of tumour mass in the caecal wall, particular in the sub-mucosa (Figure 5A and 5B). Moreover, the tumour cells could secrete mucus, as revealed by Alcian blue staining (black arrows in Figure 5C). The tumours were vascularised, and CD31-positive endothelial cells were detected within the tumour mass (black arrows in Figure 5D). These data confirmed that the model mimics a mucosal human adenocarcinoma. CD31 analysis of the tumour mass revealed that tumour cells were present within tumour vessels (black arrows in Figure 5E). HES analysis in the lungs highlighted the presence of thick and large cells within the pulmonary parenchyma, corresponding to lung metastases (Figure 5F) and explaining the strong uptake of anti-CEA pIgA in this organ (at $4 \mathrm{~h}: 42.8 \pm 59.4 \% \mathrm{ID} / \mathrm{g}$; at 8 h: $97.6 \pm 29.5 \% \mathrm{ID} / \mathrm{g})$.

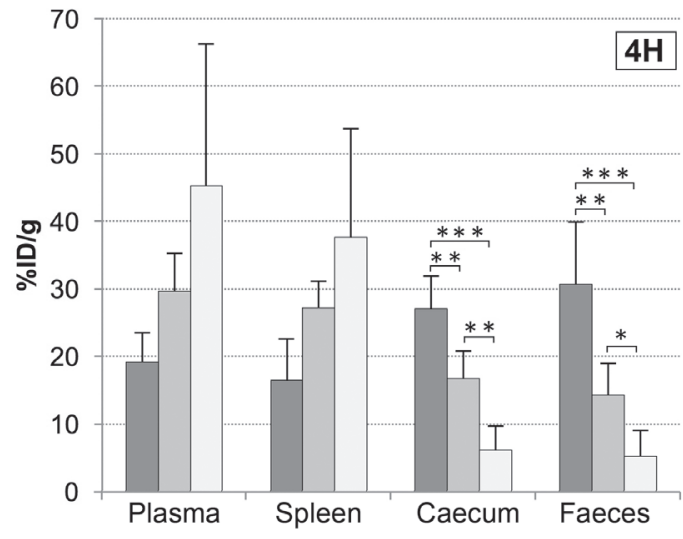

\section{$\square \mathrm{plg} A$ \\ $\square \mathrm{mlgA}$ \\ $\square \lg G$}

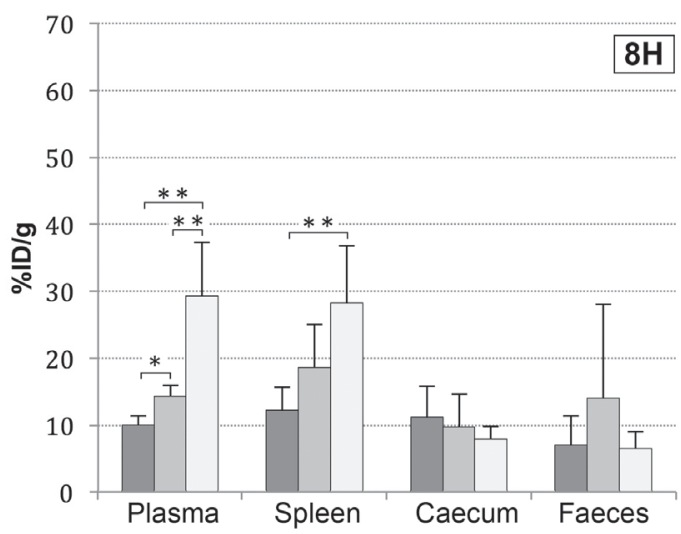

\section{$\square$ plgA \\ $\square \mathrm{mlgA}$ \\ $\square \lg G$}
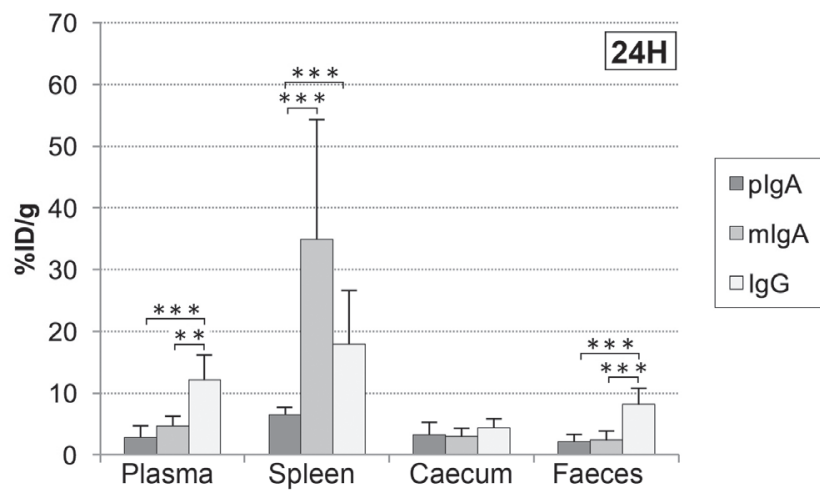

Figure 4: Biodistribution of ${ }^{99 \mathrm{~m}}$ Tc-anti-CEA pIgA-SH, ${ }^{99 \mathrm{~m}}$ Tc-anti-CEA mIgA-SH and ${ }^{99} \mathrm{~m}$ Tc-anti-CEA IgG-SH. Representation of radiolabeled Ig biodistribution at 4, 8 and 24 h post-injection in selected organs: plasma, spleen, caecum and Faeces. Values are expressed as the percentage of injected (intravenous; IV) dose per gram $\% \mathrm{ID} / \mathrm{g}$ and represent the means $\pm \mathrm{S} . \mathrm{D}$. of the $\% \mathrm{ID} / \mathrm{g}$.

$*: p$ value $<0.05 ; * *: p$ value $<0.01 ; * * *: p$ value $<0.005$ 
Table 4: Biodistribution of ${ }^{99 \mathrm{~m}} \mathrm{Tc}-\mathrm{pIgA}-\mathrm{SH}$ in nude mice bearing intracaecal tumours, and in nude healthy mice at $4 \mathrm{~h}$ and 8h, expressed as the percentage of injected dose per gram, \%ID/g (values represent means \pm SD of the \%ID/g)

\begin{tabular}{|c|c|c|c|c|c|c|}
\hline & \multicolumn{4}{|c|}{ Nude mice bearing intracecal tumours } & \multirow{2}{*}{\multicolumn{2}{|c|}{$\frac{\text { Nude healthy mice }}{\text { Anti-CEA pIgA }}$}} \\
\hline & \multicolumn{2}{|c|}{ Anti-CEA pIgA } & \multicolumn{2}{|c|}{ Irrelevant pIgA } & & \\
\hline & $\begin{array}{c}4 h \\
(n=6)\end{array}$ & $\begin{array}{c}8 \mathrm{~h} \\
(\mathrm{n}=6)\end{array}$ & $\begin{array}{c}4 h \\
(n=6)\end{array}$ & $\begin{array}{c}8 \mathrm{~h} \\
(\mathrm{n}=6)\end{array}$ & $\begin{array}{c}4 h \\
(n=4)\end{array}$ & $\begin{array}{c}8 \mathrm{~h} \\
(n=4)\end{array}$ \\
\hline Heart & $2.5 \pm 0.6$ & $2.4 \pm 1.2$ & $2.2 \pm 0.7$ & $1.3 \pm 0.08$ & $3.2 \pm 0.6$ & $2.1 \pm 0.7$ \\
\hline Brain & $0.24 \pm 0.09$ & $0.16 \pm 0.04$ & $0.20 \pm 0.06$ & $0.11 \pm 0.01$ & $0.23 \pm 0.08$ & $0.15 \pm 0.03$ \\
\hline Lungs & $42.8 \pm 59.4$ & $97.6 \pm 29.5$ & $3.8 \pm 1.5$ & $4.8 \pm 1.3$ & $13.5 \pm 10.4$ & $19.0 \pm 6.6$ \\
\hline Kidneys & $16.0 \pm 2.3$ & $17.1 \pm 4.7$ & $16.6 \pm 5.8$ & $10.4 \pm 1.5$ & $16.0 \pm 6.0$ & $12.1 \pm 0.1$ \\
\hline Spleen & $17.6 \pm 12.4$ & $14.5 \pm 7.8$ & $9.9 \pm 4.9$ & $20.9 \pm 8.1$ & $8.2 \pm 2.3$ & $7.1 \pm 1.3$ \\
\hline Stomach & $1.8 \pm 1.0$ & $1.7 \pm 0.8$ & $1.3 \pm 0.8$ & $0.9 \pm 0.3$ & $1.9 \pm 0.7$ & $1.9 \pm 1.5$ \\
\hline Small intestine & $4.6 \pm 1.7$ & $3.6 \pm 2.9$ & $4.9 \pm 2.1$ & $1.8 \pm 0.4$ & $4.7 \pm 2.0$ & $3.2 \pm 0.2$ \\
\hline Caecum (empty) & $15.8 \pm 5.5$ & $18.5 \pm 8.5$ & $16.7 \pm 6.9$ & $11.5 \pm 6.5$ & $7.9 \pm 2.5$ & $19.9 \pm 1.4$ \\
\hline Colon & $6.4 \pm 2.6$ & $3.4 \pm 1.8$ & $7.2 \pm 4.9$ & $3.2 \pm 0.8$ & $10.0 \pm 0.6$ & $4.4 \pm 0.7$ \\
\hline Liver & $50.5 \pm 20.3$ & $46.3 \pm 21.8$ & $50.3 \pm 7.2$ & $41.9 \pm 9.2$ & $34.4 \pm 1.2$ & $40.2 \pm 3.3$ \\
\hline Muscle & $0.7 \pm 0.3$ & $0.9 \pm 0.2$ & $0.8 \pm 0.2$ & $0.8 \pm 0.3$ & $0.9 \pm 0.2$ & $0.6 \pm 0.1$ \\
\hline Blood cells & $3.1 \pm 0.8$ & $2.3 \pm 0.9$ & $2.5 \pm 1.2$ & $1.3 \pm 0.2$ & $2.2 \pm 1.3$ & $0.8 \pm 0.1$ \\
\hline Plasma & $9.8 \pm 2.7$ & $8.2 \pm 5.1$ & $7.9 \pm 2.2$ & $4.4 \pm 0.4$ & $9.7 \pm 2.1$ & $5.6 \pm 0.6$ \\
\hline Feces & $34.2 \pm 24.0$ & $13.3 \pm 9.5$ & $34.9 \pm 22.9$ & $9.7 \pm 6.2$ & $35.2 \pm 12.9$ & $35.0 \pm 10.1$ \\
\hline
\end{tabular}
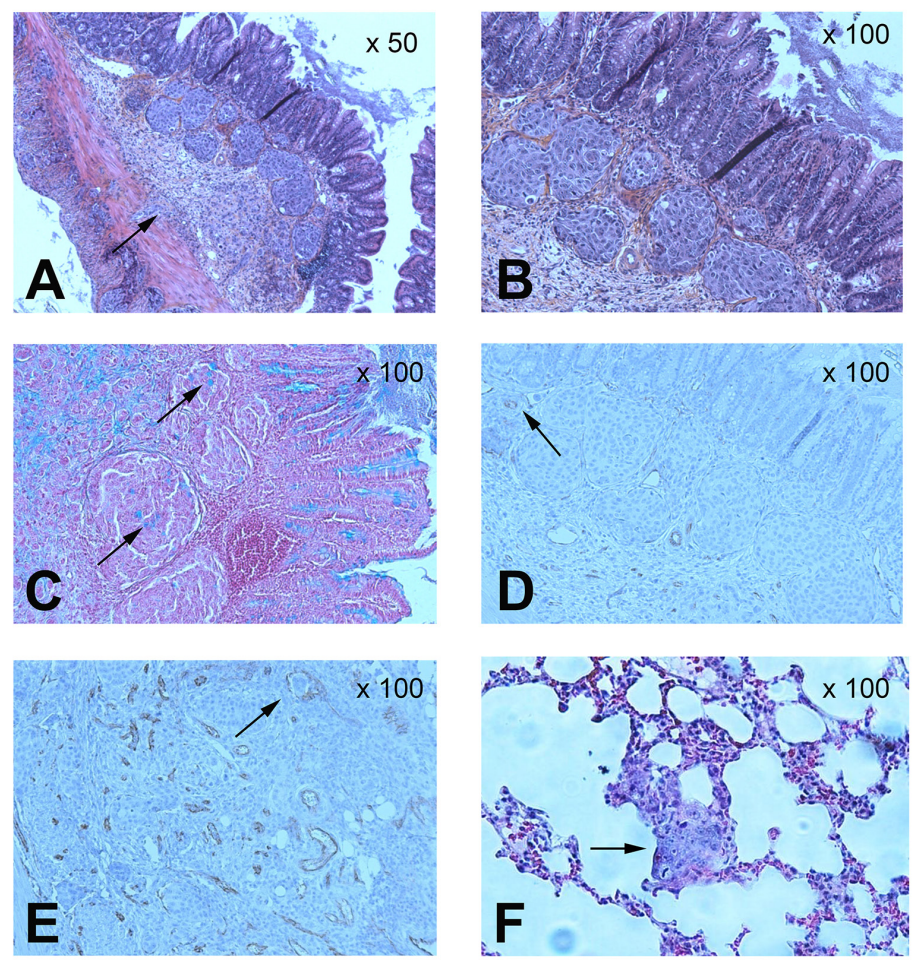

Figure 5: Pathological analysis of caecum and lungs in the tumour mouse model. Histochemical analysis of colorectal orthotopic grafts: (A) (magnification x50) and (B) (x100): haematoxylin, eosin and safran (HES) analysis. (C) (x100): mucus cells with Alcian Blue staining. (D) (x100): vessels staining with CD31. (E) (x100): tumour cells detected in caecum tumour vessels with CD31 staining. Lungs histochemical analysis: (F) (x100): HES analysis. 


\section{MicroSPECT/CT imaging of normal SCID mice and tumour bearing SCID or Tsg SCID-CD89 mice with ${ }^{99 \mathrm{~m}} \mathrm{Tc}$-anti-CEA pIgA-SH, ${ }^{99 \mathrm{~m}} \mathrm{Tc}-$ irrelevant pIgA-SH and ${ }^{99 m}$ Tc-anti-CEA IgG-SH}

Biodistribution of ${ }^{99 m} \mathrm{Tc}-a n t i-\mathrm{CEA}$ pIgA-SH, ${ }^{99 m}$ Tc-irrelevant $\mathrm{pIgA}-\mathrm{SH}$ and ${ }^{99 \mathrm{~m}} \mathrm{Tc}-\mathrm{anti}-\mathrm{CEA}$ IgGSH was subsequently evaluated $4 \mathrm{~h}$ post-injection by microSPECT/CT in normal SCID mice and in SCID and Tsg SCID-CD89 colorectal tumour model $(\mathrm{n}=3$ for each Ig and mice model).

In healthy mice, for the three Ig, an intense uptake was observed in the liver as highlighted also in the biodistribution studies. Furthermore, an intense uptake was observed in the digestive tract after injection of anti-CEA pIgA and to a lesser extent of irrelevant pIgA, whereas a low uptake of the anti-CEA IgG was revealed (Figure 6A$6 \mathrm{C})$. Total digestive activity was quantified and compared to whole body, for ${ }^{99 \mathrm{~m}} \mathrm{Tc}$-anti-CEA pIgA, ${ }^{99 \mathrm{~m}} \mathrm{Tc}$-irrelevant pIgA and ${ }^{99 m} \mathrm{Tc}-$ anti-CEA IgG and represented $32 \pm 6 \%, 19$ $\pm 8 \%$ and $8 \pm 1 \%$ respectively.

In engrafted mice, a high uptake was observed in the liver for the three Ig. An intense uptake was highlighted in the digestive tract after ${ }^{99 \mathrm{~m}} \mathrm{Tc}$-anti-CEA pIgA injection (Figure 6D and 6G), compared to the low uptake of ${ }^{99 \mathrm{~m}} \mathrm{Tc}$ anti-CEA IgG (Figure 6F and 6I). Nevertheless, the whole digestive tract uptake of ${ }^{99 \mathrm{~m}} \mathrm{Tc}$-anti-CEA pIgA didn't significantly differ between healthy and engrafted mice ( $32 \pm 6 \%$ and $30 \pm 9 \%$ respectively).

In both healthy and engrafted mice, an intense uptake of ${ }^{99 \mathrm{~m}} \mathrm{Tc}$-anti-CEA IgA was also noticed in the gallbladder ( $\mathrm{n}=9$, data not shown) whereas no significant uptake was ever observed in mice injected with the ${ }^{99 \mathrm{~m}} \mathrm{Tc}-$ anti-CEA $\operatorname{IgG}(\mathrm{n}=9$, data not shown). This result is consistent with the physiological hepato-biliary pathway of IgA.

When the uptake of IgA observed in engrafted SCID mice (Figure 6D and 6E) was compared to the uptake observed in engrafted Tsg SCID-CD89 mice (Figure 6G and $6 \mathrm{H}$ ), the contribution of $\mathrm{FC} \alpha \mathrm{RI}$ does not appear to be determinant. No significant increase uptake was observed in engrafted Tsg SCID-CD89 mice.

As the engrafted mouse models (NUDE, SCID, Tsg SCID-CD89) developed metastases in both liver and lungs, colonisation was evaluated by a sensitive real-time (TaqMan) PCR technique and compared with microSPECT/CT data. The percentage of metastases infiltration in the lungs, for both engrafted SCID and Tsg SCID-CD89 mice, reached the level of $0.0003 \%$ to $0.0052 \%$ of the lung tissue (Figure 7E). At this early stage of metastases spreading, the ${ }^{99 \mathrm{~m}} \mathrm{Tc}$-anti-CEA IgA failed to detect significant uptake by microSPECT/CT imaging (mean value in pulmonary Region of Interest (ROI): 0,5 $\pm 0,1$ in Figures $6 \mathrm{D}-6 \mathrm{G}$ and 7B-7D). However, when the tumour infiltrate represented higher colonisation $(0.08 \% \pm$ $0.01 \%$ ) of the pulmonary tissue, as observed in one mouse, a significant diffuse uptake of ${ }^{99 \mathrm{~m}} \mathrm{Tc}$-anti-CEA IgA was detected in the lung (mean value in pulmonary ROI: 1,4 in Figure 7A-7C) but no pulmonary nodule was identified in microSPECT/CT slice, while the imaging resolution was about $1 \mathrm{~mm}$. In the liver, despite a high level of colonisation quantified by PCR (data not shown) and also observed macroscopically, the uptake was important but not significantly different from healthy mice.

\section{DISCUSSION}

This work reported anti-CEA IgA radiolabelling with ${ }^{99 \mathrm{~m}} \mathrm{Tc}$ to evaluate IgA biodistribution compared with $\mathrm{IgG}$, and to estimate IgA tumour-targeting potency.

This study focused on IgA, a class of Ig that to date has been under-studied compared with IgG. Presently, IgG is the most widely used antibody in therapy and clinical trials. However, some functional limitations of $\mathrm{IgG}$, such as inadequate tissue accessibility and pharmacokinetics, and impaired interactions with effector cells, have been highlighted [21]. IgA could represent a promising alternative to $\operatorname{IgG}$, particularly to target mucosal tumours, considering that IgA constitutes the major Ig class at the mucosal surface.

To develop a soft ${ }^{99 \mathrm{~m}} \mathrm{Tc}$ radiolabelling method applicable to $\operatorname{IgA}$, which preserves the biological functions of antibody and is suitable for low-concentration samples of mAbs, we selected the method initially developed by Biechlin et al. [22] and subsequently optimised and evaluated by Carpenet et al. [20]. This method involved two steps: Ig derivatisation with a synthon, 2-IT, and IgSH radiolabelling by an indirect method using the ${ }^{99 \mathrm{~m}} \mathrm{Tc}-$ tricarbonyl core. The ${ }^{99 \mathrm{~m}} \mathrm{Tc}$-tricarbonyl core is a complex with high kinetic stability and an excellent precursor for radiolabelling various biomolecules, especially Igs. To functionalise Ig by adding SH- groups under milder conditions, and to obtain high radiolabelling yields, the 2-IT synthon was used. Our results confirmed the significant additional value of the derivatisation step for $\operatorname{IgA}$, as previously observed for $\operatorname{IgG}$ [19], allowing an RCP $>95 \%$. High RCP enables radiolabelled Ig administration without an additional purification step. The stability of radiolabelled IgA was checked over 24 $\mathrm{h}$ in PBS and murine plasma. Studies in PBS showed that IgA radiolabelling was stable. In murine plasma, the RCP decreased progressively over $24 \mathrm{~h}$, suggesting slight degradation comparable with that seen in IgG stability studies. Our stability results were also consistent with published data from Ig studies using tricarbonyl core (loss of $10-15 \%)[23,24]$ or direct labelling after disulphide bond reduction [25].

Western blot analyses indicated that the radiolabelling process did not alter the IgA global molecular structure. Affinity studies confirmed that radiolabelled IgA showed a well-preserved binding affinity $(\mathrm{Kd} \approx 25 \mathrm{nM})$. Concordant $\mathrm{Kd}$ were obtained with the two 


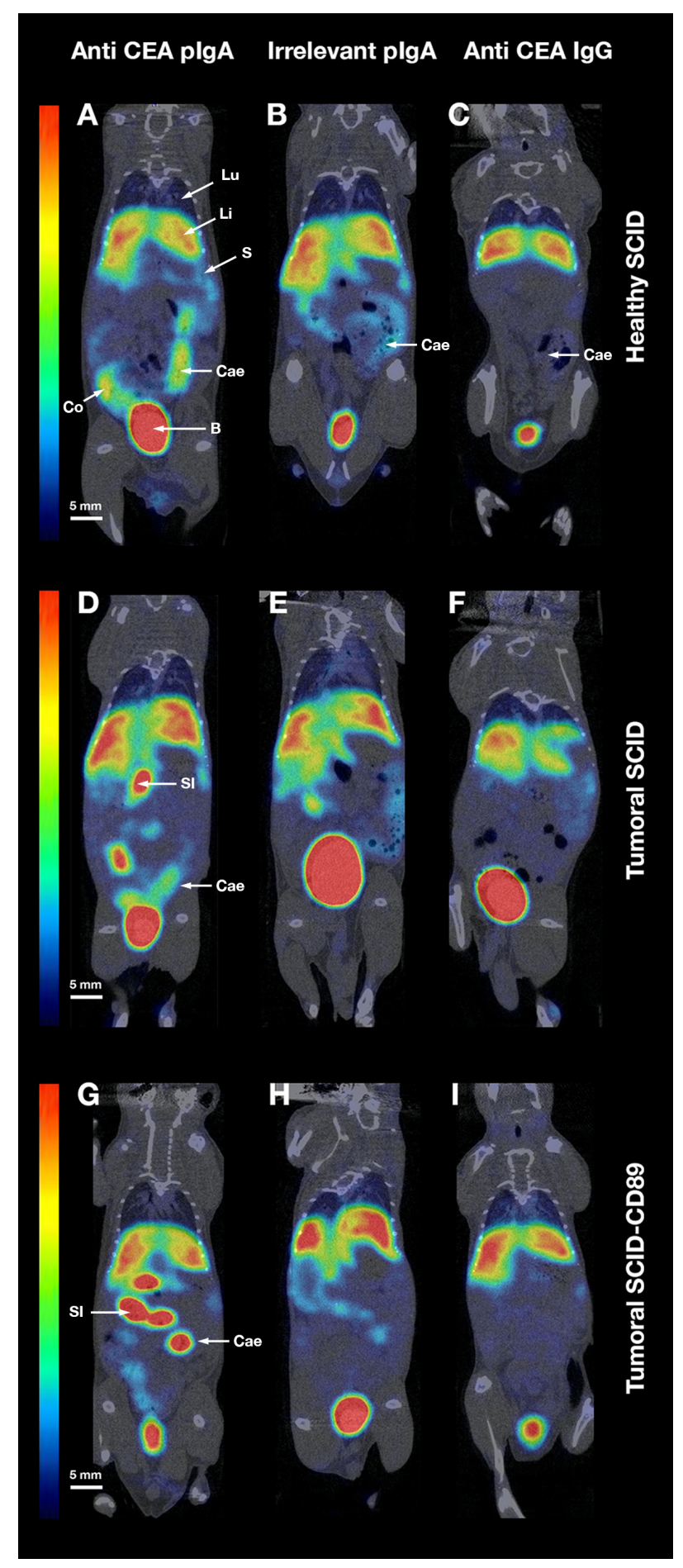

Figure 6: MicroSPECT/CT data. MicroSPECT/CT imaging of normal SCID mice (A-B-C) and tumour bearing SCID (D-E-F) or Tsg SCID-CD89 mice (G-H-I) with ${ }^{99 \mathrm{~m}}$ Tc-anti-CEA pIgA-SH (A-D-G), ${ }^{99 \mathrm{~m}}$ Tc-irrelevant pIgA-SH (B-E-H) and ${ }^{99 \mathrm{~m}} \mathrm{Tc}-\mathrm{anti}-\mathrm{CEA}$ IgG-SH (C-F-I). Tumoural mice were grafted by direct orthotopic cell microinjection of human colon carcinoma. Imaging studies were performed 6 weeks after the cell-microinjection procedure. Each mouse received 50-60 MBq of ${ }^{99 \mathrm{~m}} \mathrm{Tc}-\mathrm{Ig}$. SPECT/CT images were acquired $4 \mathrm{~h}$ post-injection for $30 \mathrm{~min}$. Representative coronal slice ( $80 \mu \mathrm{m}$ thickness) of microSPECT/CT acquisition in the different mice models/conditions:

- Healthy SCID after injection of ${ }^{99 \mathrm{~m}} \mathrm{Tc}$-anti-CEA pIgA-SH (A), ${ }^{99 \mathrm{~m}} \mathrm{Tc}-$ irrelevant pIgA-SH (B), ${ }^{99 \mathrm{~m}} \mathrm{Tc}-\operatorname{anti}-\mathrm{CEA} \operatorname{IgG}-\mathrm{SH}$ (C)

- Tumoural SCID after injection of ${ }^{99 \mathrm{~m}} \mathrm{Tc}$-anti-CEA pIgA-SH (D), ${ }^{99 \mathrm{~m}} \mathrm{Tc}$-irrelevant pIgA-SH (E), ${ }^{99 \mathrm{~m}} \mathrm{Tc}-\mathrm{anti}-\mathrm{CEA}$ IgG-SH (F)

- Tumoural Tsg SCID-CD89 after injection of ${ }^{99 \mathrm{~m} T c-a n t i-C E A}$ pIgA-SH (G), ${ }^{99 \mathrm{~m} T c-i r r e l e v a n t ~ p I g A-S H}(\mathrm{H}),{ }^{99 \mathrm{~m}} \mathrm{Tc}-\mathrm{anti}-\mathrm{CEA}$ IgG-SH (I) Principal organs were indicated with a white arrow and letters: $\mathrm{B}=$ Bladder, $\mathrm{Cae}=$ Caecum, $\mathrm{Co}=\mathrm{Colon}, \mathrm{Li}=\mathrm{Liver}, \mathrm{Lu}=\mathrm{Lung}, \mathrm{S}=\mathrm{Spleen}$, $\mathrm{SI}=$ Small Intestine. 
affinity determination methods. All of these in vitro studies suggest that radiolabelling preserves IgA functionality.

Biodistribution studies in healthy mice have compared radiolabelled $\mathrm{pIgA}, \mathrm{mIgA}$ and $\mathrm{IgG}$, all carrying the same variable domains directed against the CEA antigen. The mIgA presented an intermediate fixation profile between the profiles shown by pIgA and $\operatorname{IgG}$, except in the spleen. Although the liver is the main organ involved in IgA removal, participation of the spleen in clearance was already observed also in some cirrhosis patients and was almost invariably concurrent with normal parameters [26]. Compared with IgG, a greater and more rapid fixation (at $4 \mathrm{~h}$ ) was observed in the caecum and faeces for $\mathrm{pIgA}$ and, to a lesser extent, mIgA. This study confirms that pIgA has a strong and fast tropism for the caecum at the lamina propria, as previously described in the literature. Rapid secretion in the gut lumen and high concentration in the faeces $(4 \mathrm{~h})$ was observed; however, for $\mathrm{IgG}$, radioactivity was maximal in the faeces at $24 \mathrm{~h}$. Significant differences between $\mathrm{pIgA} / \mathrm{mIgA}$ and $\mathrm{IgG}$ were also observed in the plasma and blood-rich tissues. The plasma retention of mIgA and pIgA decreased rapidly, which is consistent with their well-known short sera halflife [27]. This appears to be balanced by their rapid rise in concentration, as observed in faeces, in accordance with the redistribution in the mucosal membrane. In mouse models, the short serum half-life of IgA antibodies seems to be partially caused by rapid clearance by the asialoglycoprotein receptor (ASGPR) recognising terminal galactose residues of $\operatorname{IgA}[28,29]$, even if this clearance pathway is more addressed to $\operatorname{Ig} \mathrm{A} 2$ than $\operatorname{IgA} 1$. In contrast, IgG is characterised by a relatively long biological halflife in the bloodstream. Unlike $\operatorname{IgA}, \operatorname{IgG}$ binds to the neonatal receptor FcRn, expressed on vascular endothelial cells, macrophages and monocytes. This interaction could be one explanation for the longer serum half-life of IgG [30]. Recently, by molecular fusion of an albuminbinding domain (ABD), the half-life and in vivo serum exposure of ABD-modified IgA was found to increase significantly due to indirect targeting of the FcRn pathway [31]. Concerning the liver, a high uptake of the three Ig isotypes studied herein was observed, explained in part by the expression of the ASGPR on the hepatocyte surface, but also by engagement of $\operatorname{IgA}$ in the hepatobiliary system involved in IgA secretion in the bile duct [32]. pIgA is transported from blood to bile without degradation [33], through hepatocytes by the pIgR. SIgA is released in the bile. Most of the pIgA that are transported from blood to bile in the liver are synthesized by plasma cells found in the lamina propria of the intestinal mucosa and enters the bloodstream at the thoracic duct. Circulating pIgA is then bound at the sinusoidal front of hepatocytes and transported across the cell, processes mediated by the pIgR. According to Hoppe's work [34], 36\% of ${ }^{125} \mathrm{I}-\mathrm{pIgA}$
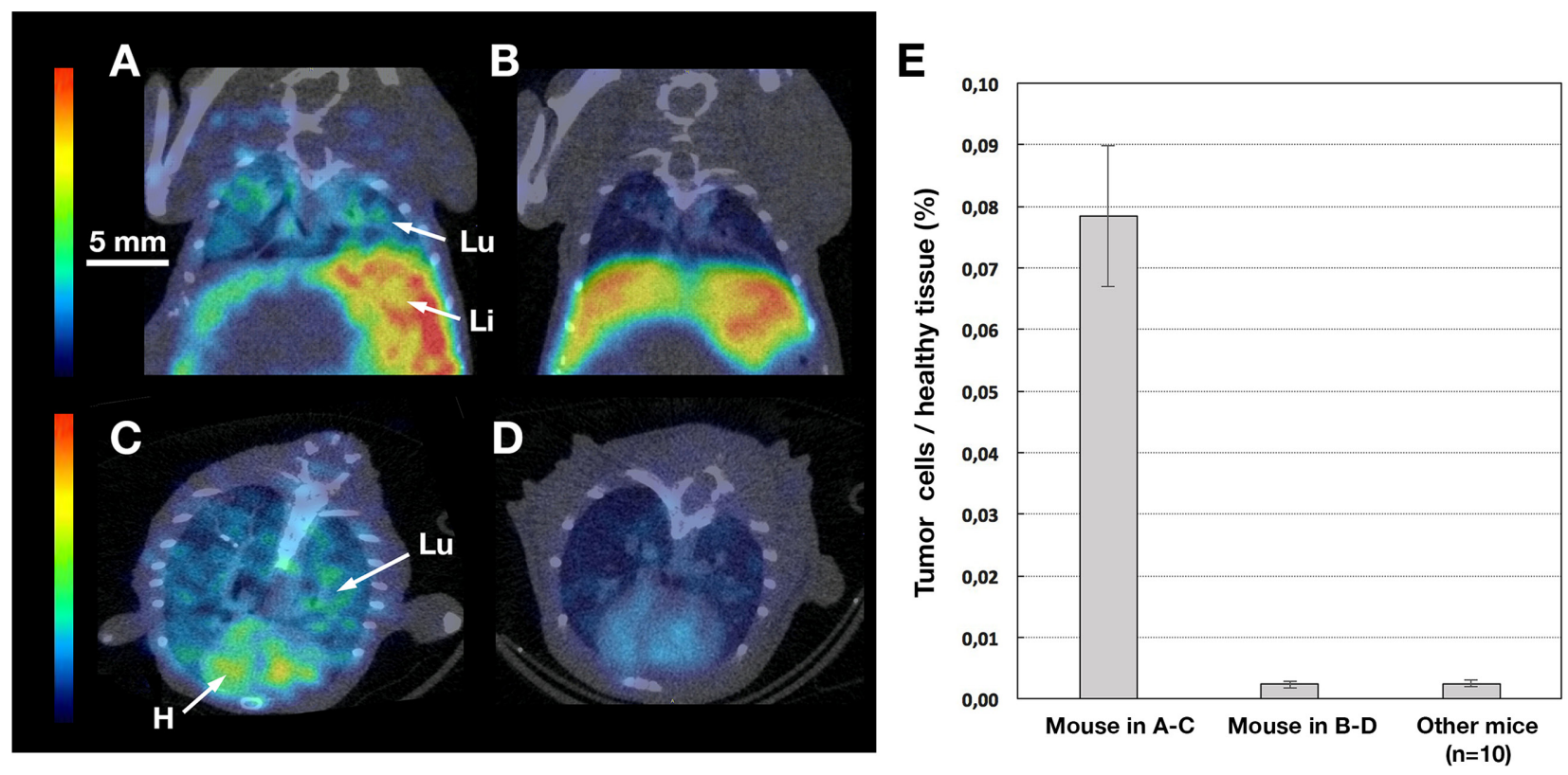

Figure 7: MicroSPECT/CT and qPCR pulmonary data. MicroSPECT/CT imaging of tumour bearing SCID with ${ }^{99 \mathrm{~m}} \mathrm{Tc}-\mathrm{anti-CEA}$ pIgA-SH (A-B-C-D) and qPCR of pulmonary sample (E). Tumoural mice were grafted by direct orthotopic cell microinjection of human colon carcinoma. Imaging studies were performed 6 weeks after the cell-microinjection procedure. Each mouse received 50-60 MBq of ${ }^{99 m}$ Tc-anti-CEA pIgA-SH. SPECT/CT images were acquired $4 \mathrm{~h}$ post-injection for $30 \mathrm{~min} .80 \mu \mathrm{m}$ thickness slice in coronal (A-B) and axial plans (C-D) of a representative view of tumour bearing SCID mice. Principal organs were indicated with a white arrow and letters: $\mathrm{H}=$ Heart, $\mathrm{Li}=$ Liver, $\mathrm{Lu}=$ Lung. The mouse in A-C was in a higher metastasis evolution (peritoneal carcinosis) than the mouse in B-D, confirmed by qPCR analysis on pulmonary samples (E). The ${ }^{99 \mathrm{~m}} \mathrm{Tc}-$ anti-CEA pIgA-SH uptake is diffuse and significantly higher in the lung of the mouse in A-C than in B-D mouse. 
(mouse myeloma producted) administrated by IV in rat, are transported as intact protein in bile over $3 \mathrm{~h}$ post-injection; the pIgA reaches its highest concentration only 30 to $60 \mathrm{~min}$ after injection, and $80 \%$ of the total of ${ }^{125} \mathrm{I}-\mathrm{pIgA}$ are finally secreted in bile by $90 \mathrm{~min}$. MicroSPECT/CT imaging confirmed and highlighted hepatobiliary system as a high uptake was observed in the gallbladder.

To evaluate IgA targeting potency, a CRC tumour model was set up in which human cancer cells were grafted in the mucosal environment. Pathological microscopic analysis clearly revealed a structural glandular architecture of the grafted tumour and the presence of large vacuoles in the WiDr cell line, consistent with muco-secretions in the lamina propria layer. Cancer cells invaded the normal caecum, under the muscle layer through the lamina propria, to produce protruding polyps in the lumen. Depending on the delay after direct orthotopic cell microinjection, different stages of $\mathrm{CRC}$ have been observed from localised tumours to metastases in the lungs. Immunohistochemical analysis in tumours revealed that tumour cells were present within tumour vessels, suggesting cellular dissemination by the vascular system. All of these factors led us to consider colorectal orthotopic grafts as being useful models of human CRC, because they share the same characteristics with human tumours. In humans, in advanced colorectal cancer, metastases are spread in the liver and lung in particular. The engrafted mouse models (NUDE, SCID, Tsg SCID-CD89) mimic metastases colonisation in both liver and lung.

Surprisingly, in post mortem biodistribution studies, no significant difference in caecum uptake was observed after the injection of radiolabelled anti-CEA IgA or irrelevant IgA, or in healthy nude mice. Tumours implanted in the external layers of the caecum progress by infiltrating the whole caecum, without an evident limit between the tumoural tissue and the healthy tissue. Caecal tumours were partly necrotic and weakly vascularised in some regions. Furthermore, pIgA, regardless of their antigenicity, have a strong tropism for caecal mucosa. So, the tumour-to-background ratio was not optimal, and radioactive determination of the whole caecum probably hampered tumour-specific signal detection. It is wellknown that, in the late stage of tumour differentiation, the majority of CEA molecules may not be reached by IVinjected mAbs because CEA is mostly expressed on the apical side of carcinoma cells hidden by the pseudo-lumen structures of the malignant glands [35]. However, human colon carcinoma cells maintained $\mathrm{pIgR}$ expression on the basolateral side on the external part of the pseudo-lumen structures. By transepithelial translocation, only dIgA, and not $\mathrm{IgG}$, can reach the pseudo-lumen to target CEA at this late stage of adenocarcinoma differentiation. Conversely, lung metastases are characterised by an immature stage of differentiation, without any glandular organisation and certainly without CEA-specific polarisation. Thus, it is interesting and important that anti-CEA pIgA uptake was observed in the lungs, at a significantly higher level than that seen after injection of radiolabelled irrelevant IgA, or in healthy nude mice. This result is consistent with the presence of lung metastases, as demonstrated by pathological analysis. Even if no significant uptake was seen in the tumoural caecum with anti-CEA pIgA, this antibody allowed the targeting of lung metastases derived from the initial colorectal tumour. Due to intrinsic mucosal tropism and biomarker affinity, pIgA could very effectively reach its target in the lungs.

The in vivo imaging by microSPECT/CT confirm that the anti-CEA pIgA is a suitable tool for the detection of mucosal tumours, particularly in lungs, but in vivo imaging is less sensitive ( $1 \mathrm{~mm}$ resolution) and uptake was detectable only for a intermediate tissue colonisation $(0.08 \% \pm 0.01 \%)$. In the liver, partly because of the high natural uptake of IgA (by the hepato-biliary pathway), the anti-CEA pIgA seems not be well adapted in detecting metastases, hide by the strong uptake background, despite a massive metastases colonisation quantified by qPCR (up to $0,9 \%$, data not show).

The FcaRI is a critical receptor to mediate cytotoxicity effect, but its involvement in pIgA biodistribution is still unclear. To investigate this pathway, microSPECT/CT studies were conducted in transgenic mice Tsg SCID-CD89. No significant increase uptake was observed in Tsg SCID-CD89 mice compared to SCID mice, neither in digestive tract, neither in lungs. This result suggests that the distribution of the $\operatorname{IgA}$ molecule could occur without active transport linked to the Fc $\alpha$ RI receptor by infiltration of myeloid cells at the mucosal site, particularly in digestive tract. In pulmonary mucosal, further investigations are necessary to clarify this preliminary report.

In conclusion, monomeric and polymeric $\operatorname{IgA}$ were efficiently and indirectly radiolabelled with ${ }^{99 \mathrm{~m}} \mathrm{Tc}$, using limited amounts of antibody. In vitro studies showed that $\operatorname{IgA}$ radiolabelling was stable and did not alter $\operatorname{IgA}$ functionality. Biodistribution studies in normal BALB/c mice, of ${ }^{99 \mathrm{~m}} \mathrm{Tc}$-anti-CEA mIgA-SH and ${ }^{99 \mathrm{~m}} \mathrm{Tc}-$ anti-CEA pIgA-SH, confirmed their shorter serum half-life and rapid and strong mucosal tropism of pIgA and, to a lesser extent, mIgA. High lung uptake of ${ }^{99 \mathrm{~m} T c-a n t i-C E A}$ pIgA-SH in the mouse tumour model suggested efficient targeting potency of $\mathrm{pIgA}$, even though a significant and specific uptake in caecum was not observed. As SIgA is resistant to intestinal degradation, it would be interesting to explore SIgA biodistribution after oral administration. SIgA reverse transcytosis, mediated by epithelial M cells, remains understudied, but in humans several receptors seem to be involved (i.e. Dectin-1, DC-SIGN [36], CD71 [37]). Finally, this work represents a first step toward IgA development to envisage, in the near future, diagnostic imaging tools and therapeutic IgA-based strategies targeting tumours in mucosal epitheliums. 


\section{MATERIALS AND METHODS}

All of the chemicals and reagents were obtained from Sigma-Aldrich (Saint-Quentin Fallavier, France) unless otherwise specified.

\section{Ig production}

All of the Ig types were produced by B Cell Design Society (Limoges, France). Monomeric and polymeric anti-CEA (relevant) or anti-peanut (irrelevant) human chimeric IgA1 were synthesised using HAMIGA ${ }^{\mathrm{TM}}$ technology [18]. For in vitro studies, a mpIgA was used; however, for in vivo studies, the enriched fraction of the mIgA or pIgA form was tested separately (purities of $95 \%$ and $85 \%$, respectively). Anti-CEA human recombinant IgG1 was synthesised after cloning the variable regions of the heavy and light chains of anti-CEA human chimeric IgA1. It was then produced in human embryonic kidney cells (HEK 293-6E; NRC, Quebec, Canada). All of the antibodies were purified by affinity chromatography using a Tricorn Column 5/100 with protein A-Sepharose at a flow rate of $1.0 \mathrm{~mL} / \mathrm{min}$ (GE Healthcare, Waukesha, WI, USA) and were eluted with glycine (0.1 M pH 2.7) equilibrated in Tris/base (1.0 M). Subsequently, IgA and IgG were dialysed against PBS by centrifugation $(1,000$ $\times g, 15 \mathrm{~min}$ ) using Amicon $30 \mathrm{kDa}$ (Millipore, SaintQuentin, France).

For imaging experiment, anti-CEA IgG was purchased (1105 clone, Fisher Scientific, Elancourt, France).

The protein concentrations were determined before and after radiolabelling using bicinchoninic Micro BC Assay ${ }^{\circledR}$ kits (Fisher Scientific, Elancourt, France), using bovine serum albumin (BSA) as a standard with quantification limits of 2.5 and $100 \mu \mathrm{g} / \mathrm{mL}$.

\section{Cell culture}

Two human colorectal cell lines were used: WiDr, a primary adenocarcinoma of the rectosigmoid [38], and DLD1, a colorectal glandular carcinoma [39]. WiDr, which are CEA-expressing cells, and DLD1, which are CEA-negative cells [40], were purchased from ATCC (Manassas, VA, USA). The two cell lines were routinely grown in RPMI and minimum essential medium, respectively, supplemented with $10 \%$ foetal calf serum, $1 \%$ sodium pyruvate, and $1 \%$ penicillin $(100 \mathrm{U} /$ $\mathrm{mL})$-streptomycin $(100 \mu \mathrm{g} / \mathrm{mL})$. For WiDr, the medium was also supplemented with $1 \%$ glutamine and $1 \%$ nonessential amino acids.

\section{Ig radiolabelling with $\left[{ }^{99 \mathrm{~m}} \mathrm{Tc}(\mathrm{CO})_{3}\left(\mathrm{H}_{2} \mathrm{O}\right)_{3}\right]^{+}$}

The radiolabelling method used has been described previously [20]. Briefly, the first step was thiol- derivatisation of Ig with 2-IT. Next, 0.5 to $2.2 \mathrm{nmol}$ IgA and IgG (300 $\mu \mathrm{L}$ in PBS) were incubated with 2-IT $\left(3.8 \mu \mathrm{M}, 25^{\circ} \mathrm{C}, 120 \mathrm{~min}\right)$. The solutions were purified by size exclusion chromatography. The number of thiol groups was determined by a micromethod using Ellman's reagent (5.5'-dithiobis-2-nitrobenzoic acid, DTNB). The second step was synthesis of the tricarbonyl precursor $\left[{ }^{99 \mathrm{~m}} \mathrm{Tc}(\mathrm{CO})_{3}\left(\mathrm{H}_{2} \mathrm{O}\right)_{3}\right]^{+}$. Next, $0.8-1 \mathrm{~mL}$ of freshly eluted $\left[\mathrm{Na}^{99 \mathrm{~m}} \mathrm{TcO}_{4}\right]$ (CisBio, Saclay, France) in fixed activities $(2,220-3,700 \mathrm{MBq})$ was added to the IsoLink $^{\circledR}$ kit (Covidien, Petten, The Netherlands) and incubated for 25 min at $100^{\circ} \mathrm{C}$. RCP analysis was performed by thin-layer chromatography (TLC) using two systems to separate the $\left[{ }^{99 \mathrm{~m}} \mathrm{Tc}(\mathrm{CO})_{3}\left(\mathrm{H}_{2} \mathrm{O}\right)_{3}\right]^{+}$from free $\left[{ }^{99 \mathrm{~m}} \mathrm{Tc}\right]$-pertechnetate, reduced ${ }^{99 \mathrm{~m}} \mathrm{Tc}$ and hydrolysed $\left[{ }^{99 \mathrm{~m}} \mathrm{Tc}(\mathrm{OH})_{\mathrm{n}}\left(\mathrm{H}_{2} \mathrm{O}\right)_{\mathrm{y}}\right]$ : (1) Baker Flex Aluminium oxide strips (JT Baker Inc., Phillipsburg, NJ, USA) - methanol/hydrochloric acid $(95 / 5 \mathrm{v} / \mathrm{v}) ;(2)$ Instant thin layer chromatography-silica gel (ITLC-SG, Varian, Les Ulis, France) - methanol. The ${ }^{99 \mathrm{~m}} \mathrm{Tc}$-Isolink ${ }^{\circledR}$ labelling yields were superior to $98 \%$. The third and last step was the radiolabelling of native or derivatised Ig with $\left[{ }^{99 \mathrm{~m}} \mathrm{Tc}(\mathrm{CO})_{3}\left(\mathrm{H}_{2} \mathrm{O}\right)_{3}\right]^{+}$. A total of $0.5-2.2$ nmol of non-derivatised IgA or thiol derivatised $\operatorname{Ig} \mathrm{A}$ (IgA$\mathrm{SH})$, or $1.5 \mathrm{nmol} \mathrm{IgG}-\mathrm{SH}$ in $300 \mu \mathrm{L}$ of PBS, was incubated for $120 \mathrm{~min}\left(25^{\circ} \mathrm{C}\right)$ with $150 \mu \mathrm{L}(148-185 \mathrm{MBq})$ of a ${ }^{99 \mathrm{~m}} \mathrm{Tc}$-tricarbonyl solution, previously neutralised to $\mathrm{pH} 7.0$ $(0.5 \mathrm{M} \mathrm{HCl})$. RCP was determined by TLC with ITLC$\mathrm{SG} / \mathrm{NaCl} 0.9 \%$.

\section{In vitro stability of ${ }^{99 \mathrm{~m}} \mathrm{Tc}-\mathrm{IgA}-\mathrm{SH}$}

The stability of radiolabelled IgA-SH was checked for $24 \mathrm{~h}$, in PBS $\left(4^{\circ} \mathrm{C}\right.$ and $\left.25^{\circ} \mathrm{C}\right)$ and murine plasma $(1 / 10$, $37^{\circ} \mathrm{C}$ ). Aliquots of $5 \mu \mathrm{L}$ were analysed by TLC (ITLC-SG/ $\mathrm{NaCl} 0.9 \%)$ at various time points $(1,2,4,16$ and $24 \mathrm{~h})$.

\section{Structural integrity of ${ }^{99 \mathrm{~m}} \mathrm{Tc}-\mathrm{IgA}-\mathrm{SH}$}

SDS-PAGE was performed under non-reducing conditions with the native or labelled Ig. The proteins (1.5-10 $\mu \mathrm{g}$ per lane) and molecular weight standards (BioRad, Hercules, CA, USA) were loaded and resolved with a Mini-Protean TGX Precast Gel using a Bio-Rad apparatus. Proteins were immediately transferred to a PVDF membrane. The membrane was then washed, blocked with a 3\% milk phosphate buffer and incubated (90 min, $\left.25^{\circ} \mathrm{C}\right)$ in diluted primary antibody solution $(1 / 1,000$, goat antihuman IgA-horseradish peroxidase; Southern Biotech, Birmingham, AL, USA). The membrane signals were revealed using the diaminobenzidine (DAB) substrate.

\section{Affinity of ${ }^{99 m}$ Tc-IgA-SH}

The binding affinity was evaluated by two complementary methods: in plate with coated CEA antigen and directly on cells expressing CEA antigen. 


\section{Binding affinity by RIA}

To evaluate anti-CEA IgA binding to human CEA, removable well plates were coated with $1 \mu \mathrm{g}$ / well of CEA antigen (AbCys SA, Courtaboeuf, France) and incubated (overnight, $4^{\circ} \mathrm{C}$ ) in $\mathrm{PBS}$ at $\mathrm{pH} 7.4$. Next, they were blocked with PBS-gelatine 2\% (1 h, $37^{\circ} \mathrm{C}$ ). Relevant (anti-CEA) or irrelevant (anti-peanut) radiolabelled IgA $(100 \mu \mathrm{L}, 0.5-16 \mu \mathrm{g} / \mathrm{mL})$ was added in series to antigen-coated wells. The first series was diluted in PBS-gelatine $0.2 \%$ and the second was diluted in PBS-gelatine $0.2 \%$ containing unlabelled antibody at $500 \mu \mathrm{g} / \mathrm{mL}$ (non-specific binding). Plates were incubated $\left(2 \mathrm{~h}, 37^{\circ} \mathrm{C}\right)$ and washed three times with PBS at $\mathrm{pH} 7.4$. The radioactivity contained in the wells was determined by gamma counting (Cobra 5003; Canberra Packard, Frankfurt, Germany).

\section{Binding affinity on cells}

Saturation binding studies were assessed according to the method of Lindmo et al. [41, 42]. The ${ }^{99 \mathrm{~m}} \mathrm{Tc}-$ IgA-SH binding affinity experiments were performed on WiDr (anti-CEA and anti-peanut $\operatorname{IgA}$ ) and DLD1 (anti-CEA IgA). Samples of cells (1 million cells/250 $\mu \mathrm{L})$ were first pre-incubated with an anti-mouse CD16/ CD32 IgG2Bk $\left(1 / 250,25^{\circ} \mathrm{C}, 30 \mathrm{~min}\right.$; BD Biosciences Pharmingen, Maharashtra, India) to block the Fc receptor. They were then pre-incubated with PBS-BSA 3\% or with unlabelled antibody (final concentration of $100 \mu \mathrm{g} /$ $\mathrm{mL}$ in PBS-BSA 3\%) to saturate the binding sites for nonspecific binding determination $\left(25^{\circ} \mathrm{C}, 90 \mathrm{~min}\right)$. Next, duplicate samples were incubated with ${ }^{99 \mathrm{~m}} \mathrm{Tc}-\mathrm{IgA}-\mathrm{SH}$ increasing concentrations $(125 \mu \mathrm{L}, 0.1$ to $10-13 \mu \mathrm{g} / \mathrm{mL})$. After incubation $\left(2 \mathrm{~h}, 25^{\circ} \mathrm{C}\right)$ with continuous rotation, the cells were filtered using Manifold $\AA$ (Millipore) and washed with PBS. Filter radioactivity was evaluated with a gamma-counter.

\section{Affinity data analysis}

For wells and cell-binding affinity studies, specific binding was evaluated by subtracting nonspecific binding (determined after incubation with unlabelled antibody) from total binding. Data analysis was performed using a Scatchard plot of the binding of ${ }^{99 \mathrm{~m}} \mathrm{Tc}-$ anti-CEA IgA$\mathrm{SH}$, and the $\mathrm{Kd}$, number of antibody binding sites/ well or cell, and $\mathrm{B}_{\max }$ of ${ }^{99 \mathrm{~m}} \mathrm{Tc}-\mathrm{anti}-\mathrm{CEA} \mathrm{IgA-SH}$ were determined.

\section{Biodistribution of ${ }^{99 \mathrm{~m}} \mathrm{Tc}-$ anti-CEA IgA-SH and ${ }^{99 m}$ Tc-anti-CEA IgG-SH in normal mice}

All in vivo experiments were performed in accordance with animal ethical rules, and all efforts were made to minimise suffering. The protocol was approved by the Comité Régional d'Ethique sur l'Expérimentation Animale du Limousin (CREEAL). Biodistribution experiments were carried out in 7-week-old male BALB/c mice (Charles River Laboratories, Chatillon-surChalaronne, L'Arbresle Cedex). ${ }^{99 m} \mathrm{Tc}-\mathrm{IgA}-\mathrm{SH}$ monomeric, ${ }^{99 \mathrm{~m}} \mathrm{Tc}-\mathrm{IgA}-\mathrm{SH}$ polymeric or ${ }^{99 \mathrm{~m}} \mathrm{Tc}-\mathrm{IgG}-\mathrm{SH}$ (40 MBq, $170 \mu \mathrm{g}$ for each antibody) was injected intravenously (IV; tail vein). Animals were euthanised, by anaesthesia and cervical dislocation, at different time points after administration ( $4 \mathrm{~h}, 8 \mathrm{~h}, 18 \mathrm{~h}, 24 \mathrm{~h}, 48 \mathrm{~h}$ post-injection). Selected tissues were excised, rinsed, and weighed, and their radioactivity levels were measured with a gammacounter. The uptake of radioactivity in these organs was expressed as $\% \mathrm{ID} / \mathrm{g}$ after correcting for radioactive decay at each time point. Blood cells, plasma, and faeces were also collected and measured. Faeces refers to faecal matter collected in the small intestine and colon during dissection. Liver and gallbladder were not separated before counting.

\section{Biodistribution and tumour uptake of ${ }^{99 m}$ Tc-anti-CEA pIgA-SH in nude mice bearing human colon carcinoma}

Direct orthotopic cell microinjection was achieved according to the method of Cespedes et al. [43].

Seven-week-old female nude mice (athymic nu/ nu; Envigo, Gannat, France) were anesthetised with ketamine $(80 \mathrm{mg} / \mathrm{kg})$ (Imalgène, Merial, Lyon, France) and xylazine $(9.6 \mu \mathrm{g} / \mathrm{kg})$ (Rompun $2 \%$; Bayer, Lyon, France) to exteriorise their caecum by laparotomy. Next, $2.10^{5} \mathrm{WiDr}$ cells, suspended in $10 \mu \mathrm{L}$ of PBS in a sterile micropipette ( $30 \mathrm{G}$ needle, $30 \mu \mathrm{L}$ syringe), were slowly injected between the mucosa and muscularis externa layers of the caecal wall, under a binocular lens with an approximate $30^{\circ}$ angle. After injection, the caecum was extensively washed with sterile PBS before reintroduction into the abdominal cavity. The laparotomy was closed by surgical suture. Animals were weighed each day. If animals demonstrated clinical alteration or weight loss, they were euthanised by anaesthesia and cervical dislocation.

\section{Biodistribution and tumour uptake}

Six weeks after the cell microinjection procedure, the animals were divided into two groups. The first group $(n=6)$ received $170 \mu \mathrm{g}$ of ${ }^{99 m} \mathrm{mc}-a n t i-C E A$ pIgA-SH (IV) and the second $(n=6)$ received $170 \mu \mathrm{g}$ of irrelevant ${ }^{99 \mathrm{~m}} \mathrm{Tc}$-pIgA-SH (corresponding to $35-37$ MBq). Nude mouse controls received the same ${ }^{99 \mathrm{~m}} \mathrm{Tc}-$ anti-CEA pIgA-SH. The animals were euthanised by anaesthesia and cervical dislocation at $4 \mathrm{~h}$ and $8 \mathrm{~h}$ after administration. Finally, the procedure described in biodistribution studies of normal mice was applied. Furthermore, the caecum was longitudinally opened, washed with PBS and counted separately from caecal faeces to evaluate luminal $\operatorname{IgA}$ presence. The caeca and lungs were fixed with buffered formalin during radioactive decay (48 h). 


\section{Histological analysis of human colorectal orthotopic grafts}

Mouse organs were transferred to $4 \%$ formol and included in paraffin after automated cycling of a dehydration system (ASP200S; Leica, Heidelberg, Germany). Next, 4- $\mu \mathrm{m}$ sections were prepared using a microtome. For histological analysis, slides were stained with haematoxylin, eosin and safran (HES analysis) or with Alcian blue (secretion mucus analysis). For vascularisation analysis, CD31 staining was performed using the VENTANA robot from the pathology department of Limoges University Hospital. In each case, a pathologist was solicited to interpret the staining.

\section{MicroSPECT/CT imaging of normal SCID mice and tumour bearing SCID or Tsg SCID-CD89 mice with ${ }^{99 \mathrm{~m}} \mathrm{Tc}$-anti-CEA pIgA-SH, ${ }^{99 \mathrm{~m}} \mathrm{Tc}-$ irrelevant pIgA-SH and ${ }^{99 m}$ Tc-anti-CEA IgG-SH}

SCID (Envigo, Gannat, France) or Tsg SCID-CD89 mice (J. Leusen, University Medical Center Utrecht, The Netherlands) were grafted as described previously for nude mice. ${ }^{99 \mathrm{~m}} \mathrm{Tc}$-anti-CEA pIgA-SH, ${ }^{99 \mathrm{~m}} \mathrm{Tc}$-irrelevant $\mathrm{pIgA}-\mathrm{SH}$ or ${ }^{99 \mathrm{~m}} \mathrm{Tc}$-anti-CEA IgG-SH (60 MBq) was injected IV. Anaesthesia induction was achieved using 3\% isoflurane and animals were maintained under general anaesthesia with 1,8\% isoflurane for the duration of imaging. Air/ Oxygen $(50 \% / 50 \%, 1,41 /$ minutes $)$ was maintained throughout anaesthesia induction and maintenance. Acquisitions were performed $4 \mathrm{~h}$ post-injection with a MicroSPECT/CT (U-SPECT4/CT, MILabs, Utrecht, The Netherlands). Images were acquired during 30 minutes and energy windows were set over the $140 \mathrm{keV}$ peaks $( \pm 20 \%)$. The SPECT resolution with ${ }^{99 \mathrm{~m}} \mathrm{Tc}$ is less than 1 $\mathrm{mm}$. Images were analysed and uptake were quantified in Region of Interest (ROI) with PMOD Software (PMOD Technologies, Zürich, Switzerland).

\section{qPCR on lung samples}

The presence of human tumour cells and metastases within engrafted mouse organs was quantified, by a TaqMan-chemistry based real-time PCR using a primer/ probe-combination described previously [44]. Briefly, two days after microSPECT/CT imaging, animals were euthanized, by anaesthesia and cervical dislocation, and lung tissue was excised, two samples (in right lobe, left lobe) of $0.02 \mathrm{~g}$ were collected. Sample DNA was extracted using a nucleoSpin Tissue kit (Macherey-Nagel, Hoerdt, France) and quantify on nanodrop quantifier (Ozyme, Montigny, France). A short fragment (467bp) of the $\alpha$-satellite region of the human chromosome 17 was amplified using a probe (Cr17-probe) 5'-labelled with the reporter fluorescent dye FAM (6-carboxyfluoresceine) and linked to a non-fluorescent quencher dye TAMRA. The reactions were performed in a Applied
Biosystems Step One Plus Real Time PCR, and analysed by the Step One software (v2.3). The PCR were run in 96-well microtiter plates with a final volume of $20 \mu \mathrm{L}$, containing $12.5 \mathrm{ng}$ of genomic DNA and $10 \mathrm{nM}$ of each primer. 45 cycles were performed. Each sample was tested twice in parallel. Serial dilutions of human carcinoma cells (WiDR cell line) in mouse lung tissue (0.02 g biopsy) served to define the TaqMan-calibration curves. In parallel, a human-mouse control PCR was set up in order to normalize DNA quantity per sample. A primer/probe combination was designed in the $\beta$-actin encoding region, to be absolutely identical both in human and in mouse sequence $(\beta$-actin Forward primer: (5' tctgcgcaagttaggttttg_3'; $\beta$-actin reverse primer: (5', gatcattgctcctcctgagc_3'; FAM $\beta$-actin_probeTAMRA: (5' tcatactcetgcttgctgatc_3') and amplified a short (211bp) fragment.

\section{Statistical analysis}

Statistical analyses were performed by applying the nonparametric Kruskal-Wallis test for antibody comparison. The tests were conducted using StatView software (ver. 5.0 ; SAS Institute, Cary, NC, USA). A $p$ value $<0.05$ was considered to indicate statistical significance.

\section{Author contributions}

Conceived and designed the experiments: I. Quelven, A. Cuvillier, H. Carpenet, J. Monteil.

Performed the experiments: H. Carpenet, A. Cuvillier, I. Quelven, O. Martin, A. Perraud.

Analyzed the data: H. Carpenet, I. Quelven, A. Cuvillier, A. Perraud.

Contributed reagents/materials/analysis tools: $\mathrm{H}$. Carpenet, A. Cuvillier, G. Champier, I. Quelven.

Wrote the paper: H. Carpenet, I. Quelven, A. Cuvillier, J. Monteil, MO. Jauberteau.

\section{ACKNOWLEDGMENTS}

Some of the work presented here was supported, in part, by the Comité d'Orientation de la Recherche sur le Cancer (CORC) en Limousin. The authors are grateful to Mallinckrodt Medical for providing IsoLink ${ }^{\circledR}$ for the research. We would also like to thank F. Dalmay (INSERM UMR-S 1094 NET) for assistance with the statistical analyses, and the Pathology Department of Limoges University Hospital for assistance with the histological analysis. We thank C. Déloménie, M. Bosselut and A. Francès (B Cell Design) for IgA production and tumoural mice model, S. Lenoir (UMR CNRS 7276) for help with Real-time QPCR experiment set up and S. Durand-Panteix (UMR CNRS 7276) for suggestions and comments on the manuscript. 


\section{CONFLICTS OF INTEREST}

The authors declare that they have no competing interests. B Cell Design Society provided support in the form of a salary for authors, A. Cuvillier and G. Champier, Ig production and molecular reagents and mice supply, but did not have any additional role in the study.

\section{FUNDING}

Some of the work presented here was supported, in part, by the Comite d'Orientation de la Recherche sur le Cancer (CORC) en Limousin. Mallinckrodt Medical provided graciously IsoLink ${ }^{\circledR}$ for the research. B Cell Design Society provided all immunoglobulins, all molecular reagents for Western Blot, real-time QPCR, immunocompromised mice and transgenic mouse model (Tsg SCID-CD89).

\section{REFERENCES}

1. Bradley CJ, Lansdorp-Vogelaar I, Yabroff KR, Dahman B, Mariotto A, Feuer EJ, Brown ML. Productivity savings from colorectal cancer prevention and control strategies. Am J Prev Med. 2011; 41:e5-14.

2. Mach JP, Chatal JF, Lumbroso JD, Buchegger F, Forni M, Ritschard J, Berche C, Douillard JY, Carrel S, Herlyn M, Steplewski Z, Koprowski H. Tumor localization in patients by radiolabeled monoclonal antibodies against colon carcinoma. Cancer Res. 1983; 43:5593-600.

3. Pinkas L, Robins PD, Forstrom LA, Mahoney DW, Mullan BP. Clinical experience with radiolabelled monoclonal antibodies in the detection of colorectal and ovarian carcinoma recurrence and review of the literature. Nucl Med Commun. 1999; 20:689-96.

4. Karube Y, Katsuno K, Takata J, Matsunaga K, Haruno M, Kuroki M, Arakawa F, Matsuoka Y, Kanda H. Radioimmunoscintigraphy using Technetium-99m-labeled parental mouse and mouse-human chimeric antibodies to carcinoembryonic antigen in athymic nude mice bearing tumor. Nucl Med Biol. 1996; 23:753-9.

5. Erb DA, Nabi HA. Clinical and technical considerations for imaging colorectal cancers with technetium-99m-labeled antiCEA Fab' fragment. J Nucl Med Technol. 2000; 28:128; quiz 21.

6. Kraeber-Bodéré F, Rousseau C, Oudoux A, Bodet-Milin C, Davodeau F, Barbet J, Faivre-Chauvet A, Chérel M. L'immuno-TEP, une nouvelle approche d'imagerie moléculaire. Médecine Nucléaire. 2010; 34:295-8.

7. Olafsen T, Wu AM. Antibody vectors for imaging. Semin Nucl Med. 2010; 40:167-81.

8. Gold P, Freedman SO. Specific carcinoembryonic antigens of the human digestive system. J Exp Med. 1965; 122:467-81.
9. Pakdel A, Naghibalhossaini F, Mokaram P, Mansooreh Jaberipour M, Hosseini A. Regulation of carcinoembryonic antigen release from colorectal cancer cells. Clin Biochem. 2011; 44:S68-9.

10. Yao Y, Yang Z, Li ZF, Gu J. Immunoscintigraphy of local recurrent rectal cancer with $99 \mathrm{mTc}$-labeled anti-CEA monoclonal antibody CL58. World J Gastroenterol. 2007; 13:1841-6.

11. Serafini AN, Klein JL, Wolff BG, Baum R, Chetanneau A, Pecking A, Fischman AJ, Hoover HC Jr, Wynant GE, Subramanian R, Goroff DK, Hanna MG Jr. Radioimmunoscintigraphy of recurrent, metastatic, or occult colorectal cancer with technetium 99m-labeled totally human monoclonal antibody 88BV59: results of pivotal, phase III multicenter. J Clin Oncol. 1998; 16:1777-87.

12. Woof JM, Mestecky J. Mucosal immunoglobulins. Immunol Rev. 2005; 206:64-82.

13. Monteiro RC, Van De Winkel JG. IgA Fc receptors. Annu Rev Immunol. 2003; 21:177-204.

14. Launay P, Grossetête B, Arcos-Fajardo M, Gaudin E, Torres SP, Beaudoin L, Patey-Mariaud de Serre N, Lehuen A, Monteiro RC. Fcalpha receptor (CD89) mediates the development of immunoglobulin A (IgA) nephropathy (Berger's disease). Evidence for pathogenic soluble receptor-Iga complexes in patients and CD89 transgenic mice. J Exp Med. 2000; 191:1999-2009.

15. Bakema JE, van Egmond M. The human immunoglobulin A Fc receptor Fc $\alpha$ RI: a multifaceted regulator of mucosal immunity. Mucosal Immunol. 2011; 4:612-24.

16. Lohse S, Derer S, Beyer T, Klausz K, Peipp M, Leusen JH, van de Winkel JG, Dechant M, Valerius T. Recombinant dimeric IgA antibodies against the epidermal growth factor receptor mediate effective tumor cell killing. J Immunol. $2011 ; 186: 3770-8$.

17. Fagarasan S, Kinoshita K, Muramatsu M, Ikuta K, Honjo T. In situ class switching and differentiation to IgA-producing cells in the gut lamina propria. Nature. 2001; 413:639-43.

18. Duchez S, Amin R, Cogné N, Delpy L, Sirac C, Pascal $\mathrm{V}$, Corthésy B, Cogné M. Premature replacement of mu with alpha immunoglobulin chains impairs lymphopoiesis and mucosal homing but promotes plasma cell maturation. Proc Natl Acad Sci U S A. 2010; 107:3064-9.

19. Camacho X, García MF, Calzada V, Fernández M, Chabalgoity JA, Moreno M, Barbosa de Aguiar R, Alonso O, Gambini JP, Chammas R, Cabral P. [(99m) $\mathrm{Tc}(\mathrm{CO})(3)]$-radiolabeled bevacizumab: in vitro and in vivo evaluation in a melanoma model. Oncology. 2013; 84:200-9.

20. Carpenet H, Cuvillier A, Monteil J, Quelven I. Anti-CD20 immunoglobulin $\mathrm{G}$ radiolabeling with a ${ }^{99 \mathrm{~m}} \mathrm{Tc}$-tricarbonyl core: in vitro and in vivo evaluations. PLoS One. 2015; 10:e0139835.

21. Beckman RA, Weiner LM, Davis HM. Antibody constructs in cancer therapy: protein engineering strategies to improve exposure in solid tumors. Cancer. 2007; 109:170-9. 
22. Biechlin ML, d'Hardemare A du M, Fraysse M, Gilly FN, Bonmartin A. Improvement in radiolabelling proteins with the ${ }^{99 \mathrm{~m}} \mathrm{Tc}$-tricarbonyl-core $\left[{ }^{99 \mathrm{~m}} \mathrm{Tc}(\mathrm{CO})_{3}\right]^{+}$, by thiolderivatization with iminothiolane: application to $\gamma$-globulins and annexin V. J Label Comp Radiopharmaceut. 2005; 48:873-85.

23. Stopar TG, Mlinaric-Rascan I, Fettich J, Hojker S, Mather SJ. (99m)Tc-rituximab radiolabelled by photo-activation: a new non-Hodgkin's lymphoma imaging agent. Eur J Nucl Med Mol Imaging. 2006; 33:53-9.

24. Dias CR, Jeger S, Osso JA Jr, Müller C, De Pasquale C, Hohn A, Waibel R, Schibli R. Radiolabeling of rituximab with (188)Re and (99m)Tc using the tricarbonyl technology. Nucl Med Biol. 2011; 38:19-28.

25. Malviya G, Anzola KL, Podestà E, Laganà B, Del Mastro C, Dierckx RA, Scopinaro F, Signore A. (99m)Tc-labeled rituximab for imaging $\mathrm{B}$ lymphocyte infiltration in inflammatory autoimmune disease patients. Mol Imaging Biol. 2012; 14:637-46.

26. Roccatello D, Picciotto G, Torchio M, Ropolo R, Ferro M, Franceschini R, Quattrocchio G, Cacace G, Coppo R, Sena LM. Removal systems of immunoglobulin $\mathrm{A}$ and immunoglobulin A containing complexes in IgA nephropathy and cirrhosis patients. The role of asialoglycoprotein receptors. Lab Invest. 1993; 69:714-23.

27. Monteiro RC. Role of $\operatorname{IgA}$ and $\operatorname{IgA}$ fc receptors in inflammation. J Clin Immunol. 2010; 30:1-9.

28. Stockert RJ, Kressner MS, Collins JC, Sternlieb I, Morell AG. IgA interaction with the asialoglycoprotein receptor. Proc Natl Acad Sci U S A. 1982; 79:6229-31.

29. Rifai A, Fadden K, Morrison SL, Chintalacharuvu KR. The $\mathrm{N}$-glycans determine the differential blood clearance and hepatic uptake of human immunoglobulin (Ig)A1 and IgA2 isotypes. J Exp Med. 2000; 191:2171-82.

30. Roopenian DC, Akilesh S. FcRn: the neonatal Fc receptor comes of age. Nat Rev Immunol. 2007; 7:715-25.

31. Meyer S, Nederend M, Jansen JH, Reiding KR, Jacobino SR, Meeldijk J, Bovenschen N, Wuhrer M, Valerius T, Ubink R, Boross P, Rouwendal G, Leusen JH. Improved in vivo anti-tumor effects of IgA-Her2 antibodies through halflife extension and serum exposure enhancement by FcRn targeting. MAbs. 2016; 8:87-98.

32. Harmatz PR, Kleinman RE, Bunnell BW, McClenathan DT, Walker WA, Bloch KJ. The effect of bile duct obstruction on the clearance of circulating IgA immune complexes. Hepatology. 1984; 4:96-100.

33. Orlans E, Peppard J, Reynolds J, Hall J. Rapid active transport of immunoglobulin A from blood to bile. J Exp Med. 1978; 147:588-92.

34. Hoppe CA, Connolly TP, Hubbard AL. Transcellular transport of polymeric IgA in the rat hepatocyte: biochemical and morphological characterization of the transport pathway. J Cell Biol. 1985; 101:2113-23.

35. Buchegger F, Pfister C, Fournier K, Prevel F, Schreyer M, Carrel S, Mach JP. Ablation of human colon carcinoma in nude mice by $131 \mathrm{I}$-labeled monoclonal anticarcinoembryonic antigen antibody F(ab')2 fragments. J Clin Invest. 1989; 83:1449-56.

36. Rochereau N, Drocourt D, Perouzel E, Pavot V, Redelinghuys P, Brown GD, Tiraby G, Roblin X, Verrier B, Genin C, Corthésy B, Paul S. Dectin-1 is essential for reverse transcytosis of glycosylated SIgA-antigen complexes by intestinal M cells. PLoS Biol. 2013; 11:e1001658.

37. Lebreton C, Ménard S, Abed J, Moura IC, Coppo R, Dugave C, Monteiro RC, Fricot A, Traore MG, Griffin M, Cellier C, Malamut G, Cerf-Bensussan N, Heyman M. Interactions among secretory immunoglobulin A, CD71, and transglutaminase- 2 affect permeability of intestinal epithelial cells to gliadin peptides. Gastroenterology. 2012; 143:698-707.e4.

38. Flatmark K, Mælandsmo GM, Martinsen M, Rasmussen H, Fodstad Ø. Twelve colorectal cancer cell lines exhibit highly variable growth and metastatic capacities in an orthotopic model in nude mice. Eur J Cancer. 2004; 40:1593-8.

39. Maréchal R, De Schutter J, Nagy N, Demetter P, Lemmers A, Devière J, Salmon I, Tejpar S, Van Laethem JL. Putative contribution of CD56 positive cells in cetuximab treatment efficacy in first-line metastatic colorectal cancer patients. BMC Cancer. 2010; 10:340.

40. Guadagni F, Witt PL, Robbins PF, Schlom J, Greiner JW. Regulation of carcinoembryonic antigen expression in different human colorectal tumor cells by interferongamma. Cancer Res. 1990; 50:6248-55.

41. Lindmo T, Boven E, Cuttitta F, Fedorko J, Bunn PA Jr. Determination of the immunoreactive fraction of radiolabeled monoclonal antibodies by linear extrapolation to binding at infinite antigen excess. J Immunol Methods. 1984; 72:77-89.

42. Lindmo T, Bunn PA Jr. Determination of the true immunoreactive fraction of monoclonal antibodies after radiolabeling. Meth Enzymol. 1986;121:678-91.

43. Céspedes MV, Espina C, García-Cabezas MA, Trias M, Boluda A, Gómez del Pulgar MT, Sancho FJ, Nistal M, Lacal JC, Mangues R. Orthotopic microinjection of human colon cancer cells in nude mice induces tumor foci in all clinically relevant metastatic sites. Am J Pathol. 2007; 170:1077-85.

44. Becker M, Nitsche A, Neumann C, Aumann J, Junghahn I, Fichtner I. Sensitive PCR method for the detection and realtime quantification of human cells in xenotransplantation systems. Br J Cancer. 2002; 87:1328-35. 